\title{
Loess in eastern equatorial Pangea archives a dusty atmosphere and possible upland glaciation
}

\author{
Lily S. Pfeifer ${ }^{1, \dagger}$, Gerilyn S. Soreghan ${ }^{1}$, Stéphane Pochat ${ }^{2}$, and Jean Van Den Driessche ${ }^{3}$ \\ ${ }^{1}$ School of Geosciences, University of Oklahoma, 100 East Boyd Street, Norman, Oklahoma 73019, USA \\ ${ }^{2}$ CNRS UMR 6112, Université de Nantes, Laboratoire de Planétologie et de Géodynamique, 2 rue de la Houssinière, \\ Nantes F-44000, France \\ ${ }^{3}$ Université de Rennes, CNRS, Géosciences Rennes-UMR 6118, F-35000 Rennes, France
}

\section{ABSTRACT}

Carboniferous-Permian strata in basins within the Central Pangean Mountains in France archive regional paleoequatorial climate during a unique interval in geological history (Pangea assembly, ice-age collapse, megamonsoon inception). The voluminous $(\sim 1.5 \mathrm{~km})$ succession of exclusively finegrained red beds that comprises the Permian Salagou Formation (Lodève Basin, France) has long been interpreted to record either lacustrine or fluvial deposition, primarily based on a local emphasis of subaqueous features in the upper $\sim \mathbf{2 5 \%}$ of the section. In contrast, data presented here indicate that the lowermiddle Salagou Formation is dominated by up to 15-m-thick beds of internally massive red mudstone with abundant pedogenic features (microscale) and no evidence of channeling. Up-section, limited occurrences of ripple and hummocky cross-stratification, and mudcracks record the intermittent influence of shallow water, but with no channeling nor units with grain sizes exceeding coarse silt. These data suggest that the most parsimonious interpretation for the Salagou Formation involves eolian transport of the sediment and ultimate deposition as loess in shallow, ephemeral lacustrine environments. Provenance analyses of the Salagou Formation indicate coarse-grained protoliths and, together with geochemical proxies (chemical index of alteration [CIA] and $\tau_{\mathrm{Na}}$ ) that correspond respectively to a low degree of chemical weathering and a mean annual temperature of $\sim 4{ }^{\circ} \mathrm{C}$, suggest that silt generation in this case is most consistent with cold-weathering (glacial and associated periglacial) processes in the Variscan highlands. Together with previous studies that detailed voluminous Permian loess in western equatorial Pangea, this

\footnotetext{
†1spfeifer@ou.edu
}

work shows a globally unique distribution of dust at low latitudes that can be linked either directly to glaciated alpine terranes or to reworked and deflated deposits of other types (e.g., fluvial outwash) where fine-grained material was originally generated from glacial grinding in alpine systems. These results further support a revised model for early Permian climate, in which extratropical ice sheets coexisted with a semiarid tropics that may have hosted significant ice at moderate elevation.

\section{INTRODUCTION}

Ancient (pre-Quaternary) loess deposits record valuable information about paleoclimate and are well recognized in the Upper Paleozoic record of western equatorial Pangea (e.g., Murphy, 1987; Johnson, 1989; Kessler et al., 2001; Soreghan et al., 2002, 2008a, 2014b; Soreghan and Soreghan, 2007; Mack and Dinterman, 2002; Tramp et al., 2004; Sweet et al., 2013; Giles et al., 2013; Foster et al., 2014). The paleoclimatic significance of voluminous Upper Paleozoic loess, particularly in equatorial latitudes, remains debated: Some argue for a periglacial derivation (glacial grinding and eolian deflation; Soreghan and Soreghan, 2007, 2008; Soreghan et al., 2008b, 2009, 2014a, 2014b), and others argue for a peridesert origin (e.g., reworking of eolian dunes; Johansen, 1988). In either case, loess deposits represent semiarid conditions that—relative to Quaternary Earth—are unusual for equatorial regions (Chan and Archer, 2003; Muhs and Bettis, 2003; Soreghan et al., 2008a). Global paleogeography in the late Paleozoic was governed by the assembly of Pangea, and formation of the low-latitude Central Pangean Mountains, which spanned from the VariscanHercynian system of Europe (Ziegler et al., 1979; Ziegler, 1996) west to the AppalachianOuachita-Marathon uplifts of North America. Interpretations of loess production in the deep- time record vary; however, if late Paleozoic loess in the western United States has an inferred origin in low-latitude, upland periglacial processes (e.g. Soreghan and Soreghan, 2007; Sweet and Soreghan, 2008; Soreghan et al., 2008a, 2008b, 2009, 2014a, 2014b), then deposits in the Central Pangean Mountains in eastern equatorial Pangea (western Europe) might reflect similar controls on sedimentation across the low-latitude upland regions of the supercontinent.

Carboniferous-Permian strata in basins that formed as a result of postorogenic collapse of the Variscan Mountains (eastern Central Pangean Mountains) in France preserve an unusually complete record of highland-proximal sedimentation in the late Paleozoic. In this paper, we document the sedimentology of the Permian Salagou Formation, an $\sim 1.5$-km-thick monotonous succession of exclusively fine-grained red beds in the Lodève Basin (Massif Central, southcentral France), long interpreted to record either fluvial floodplain or lacustrine depositional settings. This work presents new interpretations for these strata that have implications for our understanding of paleoequatorial climate during the decline of the late Paleozoic icehouse, and it also contributes to our repertoire of methods for recognizing well-lithified, diagenetically altered loessite in the deep-time record.

\section{GEOLOGIC BACKGROUND}

\section{Geologic Setting}

The Variscan orogeny was a complex arccontinent collision (Matte, 1986) involving long-lived (ca. 500-290 Ma) convergence and extensive crustal shortening (>600 km), followed by mid-late Carboniferous gravitational collapse of the overthickened crust (e.g., Ménard and Molnar, 1988; Burg et al., 1994). Several discrete Carboniferous-Permian continental rift basins in the French Massif Central (Fig. 1) record subsequent

GSA Bulletin;

https://doi.org/10.1130/B35590.1; 6 figures; 2 tables; 1 supplemental file. 


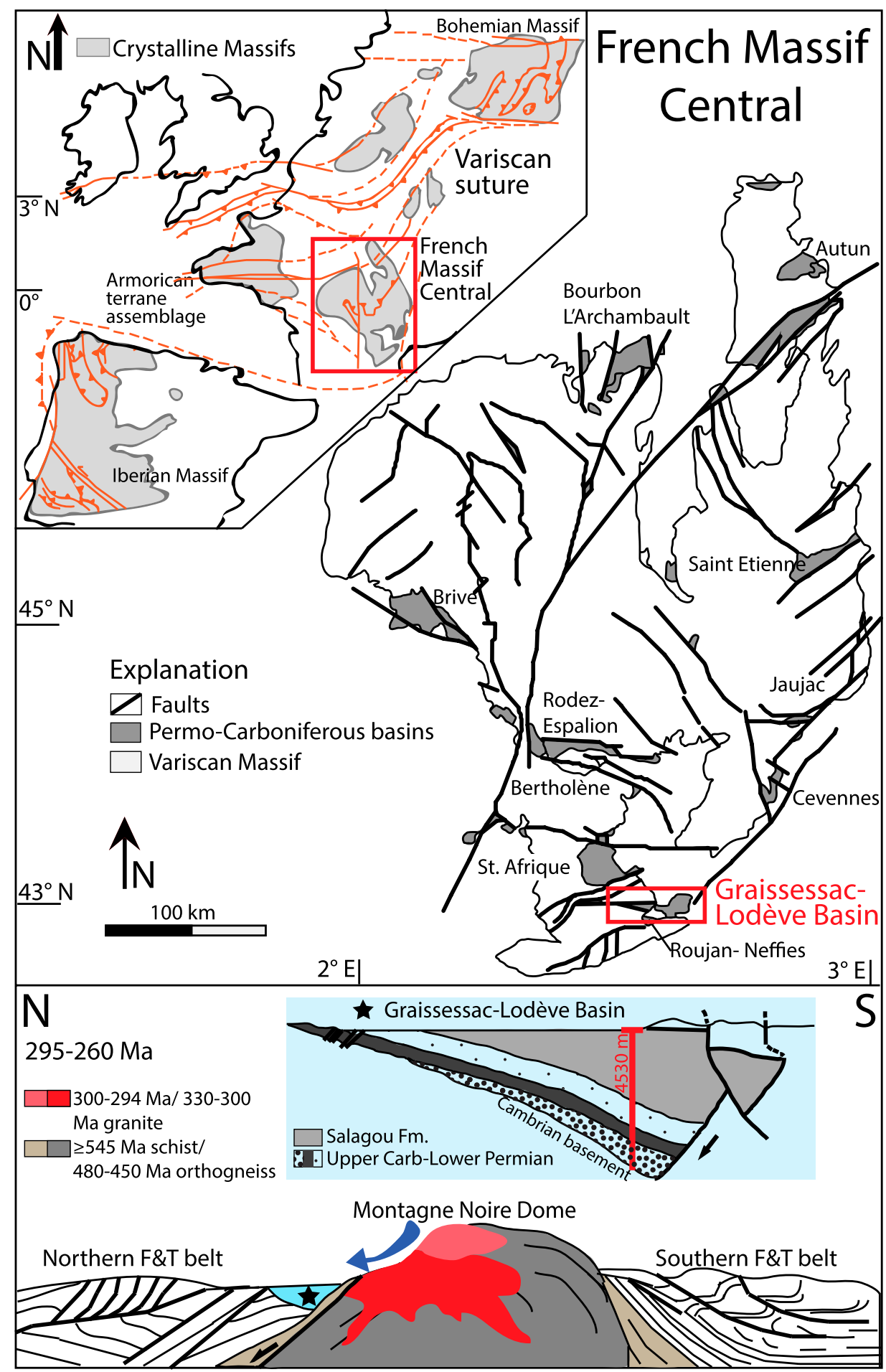

development of extensional detachment faults as well as extensional reactivation of long-lived Variscan faults (Van Den Driessche and Brun, 1989; Malavieille et al., 1990; Burg et al., 1994). These basins remained within the equatorial belt throughout the late Paleozoic and archive regional paleoequatorial climate during the collapse of the late Paleozoic icehouse.
Figure 1. Structural map of the Massif Central showing the location of CarboniferousPermian continental rift basins (dark gray) that formed as a result of extension associated with gravity collapse of the Variscan Mountains ca. 300 Ma. Inset: Late Paleozoic reconstruction of western Europe during the Variscan orogeny (ca. 320-300 Ma) showing the crystalline massifs (gray) and periGondwanan arc terranes wedged between Laurasia and Gondwana. Cross section: Carboniferous-Permian strata in the Graissessac-Lodève Basin cover $\sim 150 \mathbf{~ k m}^{2}$ and are bordered to the south by the Montagne Noire metamorphic core complex-a Variscan paleohigh that sourced the sediment in the basin (Pfeifer et al., 2016). Montagne Noire dome is color-coded by generalized ages of the predominant geologic units within the structure. The lower (Upper Carboniferous-Lower Permian) "gray facies" include a coarse, basal conglomerate, and fluvialalluvial, deltaic, and lacustrine sands and muds. Transition up section to the Permian "red facies" begins with fluvial-lacustrine sandstone, mudstone, and conglomerate, and transitions up section to exclusively finegrained (mudstone-siltstone) strata in the Salagou Formation. F\&T-fold-and-thrust. Figure is modified after Pfeifer et al. (2016).

the Permian (Parrish, 1993; Tabor and Poulsen, 2008). Late Paleozoic Gondwanan glaciation is supported by abundant geologic evidence and is inferred to reflect several fundamental forcing mechanisms that cooled Earth, such as low $p \mathrm{CO}_{2}$ and solar luminosity (Crowley et al., 1991; Montañez et al., 2007), potentially augmented by elevated sulfate aerosols produced by explosive volcanism (Soreghan et al., 2019). Hypothesized upland glaciation in the Variscan paleomountains of eastern equatorial Pangea was originally posited by Julien (1895), followed by several others (Grangeon, 1960; Dewolf, 1988; Sabrier et al., 1993; Becq-Giraudon and Van Den Driessche, 1994; Becq-Giraudon et al., 1996), but it remains controversial and not generally accepted. Paleoaltitude estimates for the Variscan Mountains range widely $(<1000$ to $>5000 \mathrm{~m}$; e.g., Becq-Giraudon and Van Den Driessche, 1994; Becq-Giraudon et al., 1996; Keller and Hatcher, 1999; Fluteau et al., 2001; Schneider et al., 2006; Roscher and Schneider, 2006).

\section{Lodève Basin}

The Graissessac-Lodève Basin, southernmost Massif Central (Fig. 1), is one of several extensional continental basins that recorded late- 
stage Variscan collapse. It remained in equatorial latitudes $\left(\sim 5^{\circ} \mathrm{S}\right.$ to $\sim 15^{\circ} \mathrm{N}$ throughout the late Paleozoic; Domeier and Torsvik, 2014; Muttoni and Kent, 2019) and preserves one of the thickest, most complete, and well-exposed records of Upper Paleozoic strata in Europe, and it is well correlated to other European CarboniferousPermian basins (Körner et al., 2003), such as the St. Affrique and Rodez basins to the north (e.g., Hübner et al., 2011). Sediment was sourced from the west and southwest basin margins (Odin, 1986; Pochat and Van Den Driessche, 2011), primarily from rapid (1-17 mm/yr) exhumation of the Montagne Noire metamorphic core complex ca. 300-285 Ma (Pfeifer et al., 2016). The lower (Upper Carboniferous-Lower Permian) "gray facies" accumulated in inferred ever-wet, fluvial-alluvial, deltaic and deep-lacustrine environments, and it transitions up section to the Permian "red facies," composed of continental red beds interpreted to record deposition in fluvial floodplain, deltaic, and playa-lake environments (e.g., Fig. 1; Odin, 1986; Gand et al., 1997; Körner et al., 2003; Pochat et al., 2005; Schneider et al., 2006; Roscher and Schneider, 2006; Lopez et al., 2008; Pochat and Van Den Driessche, 2011). This gray-to-red transition (Lower Permian) is widely interpreted to reflect increased aridity and seasonality during the collapse of the late Paleozoic icehouse (Körner et al., 2003; Schneider et al., 2006; Roscher and Schneider, 2006; Lopez et al., 2008; Michel et al., 2015a), but others posit that this shift records a tectonic evolution (enlargement of the extensional basin) with superimposed climatic variation (Pochat and Van Den Driessche, 2011). Lodève Basin strata subsequently underwent deep $(\sim 3 \mathrm{~km})$ burial and high geothermal heat flow (up to $610{ }^{\circ} \mathrm{C}$ in the western Graissessac Basin; Copard et al., 2000) and thus are moderately to severely diagenetically overprinted. Diagenesis precludes paleoenvironmental reconstructions (e.g., $p \mathrm{CO}_{2}$ ) based on paleopedological isotopic analyses and clay mineralogy (e.g., Schneider et al., 2006; Quast et al., 2006; Michel, 2009; Michel et al., 2015a).

\section{Salagou Formation}

The Permian Salagou Formation consists of an estimated 1500-1700 m of fine-grained red beds. They resemble the voluminous finegrained Permian red beds of western equatorial Pangea (e.g., Soreghan et al., 2008a) studied in many regions of the southwestern and midcontinental United States that have been interpreted as ancient loess deposits (Murphy, 1987; Johnson, 1989; Kessler et al., 2001; Soreghan et al., 2002; Mack and Dinterman, 2002; Tramp et al., 2004; Soreghan and Soreghan, 2007; Sweet et al., 2013; Giles et al., 2013; Foster et al., 2014). The Sala- gou Formation is thought to have accumulated over several million years, but dates remain in flux. The Rabejac Formation, immediately below the Salagou Formation, is middle Artinskian in age, based on the age of the lowest ash bed in the Salagou Formation (284.4 Ma; Michel et al., 2015a) and tetrapod footprints (Schneider et al., 2019). Magnetostratigraphy from Evans (2012) indicated that the Salagou Formation lies within the Kiaman superchron (>262 Ma), confirmed by $\mathrm{U}-\mathrm{Pb}$ dating on inferred tuffs in the lowermid-Salagou Octon Member (Michel et al., 2015a) ranging from 284.4 to $282.9 \mathrm{Ma}$, but the latter dates have been disputed (Pochat and Van Den Driessche, 2015; Michel et al., 2015b).

Previous studies of the Salagou Formation have recognized two primary members within the formation: the Octon Member (lower-middle Salagou, $\sim 1200 \mathrm{~m}$ ) and the Merifons Member (upper Salagou, $\sim 600 \mathrm{~m}$ ), wherein the Merifons transition is defined by a sudden increase in thin silt to fine sand calcareous interbeds (e.g., Körner, 2006; Schneider et al., 2006). At the western margin of the basin, there is an abrupt transition from "dry" (playa) red beds (Salagou Formation) to "wet" (alluvial-fluvial) red beds (upper Merifons Member to La Lieude Formation and La Tour-sur-Orb fanglomerates), but no chronostratigraphic data exist for the La Lieude Formation aside from the tetrapod track ichnofauna that provides a Guadalupian age (Schneider et al., 2010, 2019). These coarse-grained deposits are stratigraphically above the majority of the Salagou Formation ( $\sim 1.5 \mathrm{~km}$ of the Octon Member to lower Merifons Member described in this paper).

A predominance of features in the upper $\sim 25 \%$ of the Salagou Formation (Merifons Member) bears evidence of waterlain deposition, leading to prevailing interpretations that advocate either fluvial floodplain or playa-lake deposition (Odin, 1986; Pochat et al., 2005; Schneider et al., 2006; Lopez et al., 2008; Pochat and Van Den Driessche, 2011). Yet, the majority of the section below this point (Octon Member-lower Merifons Member) is internally structureless and lacks evidence for fluvial deposition (e.g., channelization, crossstratification, unidirectional paleocurrent indicators, evidence for floodplain deposition such as climbing ripples, or even laminae). Environmental interpretations include (1) a semiarid, fluctuating shallow playa lake (Merifons Member; westernmost part of basin) that graded eastward into a vast, sporadically flooded plain (Odin, 1986), (2) a playa floodplain with ephemeral lakes and Vertisol to calcic Vertisol horizons, where desiccation features represent overbank deposits or sheetflood events that mobilized fine detritus (Schneider et al., 2006; Lopez et al., 2008; Michel et al., 2015a), and (3) a large, oxic lake (Pochat et al., 2005; Pochat and Van Den Driessche, 2011), where the consistent orientation of wave ripples in the upper part of the formation records stable climate, S-SW-directed wind (present-day coordinates), and estimated water depths of $\sim 6-50 \mathrm{~m}$ during the mid- to Late Permian (Pochat et al., 2005; Pochat and Van Den Driessche, 2011).

\section{METHODS}

\section{Facies Analysis}

In total, a 1015 m section of the Salagou Formation (concatenation of nine 70-200 m sections; Fig. 2) was measured and described at decimeter scale to assess spatial and temporal variations in the stratigraphy. Hand samples for grain-size analysis and thin-section petrography were collected every 5-10 m. Suspected paleosols were described following terminology from Brewer (1976), Mack et al. (1993), and Retallack (2001). The Salagou Formation has not been measured and described at decimeter scale detail previously, though it has appeared in theses (Körner, 2006 [in German]). Prior estimates of its thickness ( $2000 \mathrm{~m}$; Pochat et al., 2005; Schneider et al., 2006) derived from its map pattern (Fig. 2) may be overestimated.

\section{Relative Grain-Size Analysis}

Owing to sample lithification that precluded disaggregation, relative grain-size analysis (quartz size fraction; Table 1) was conducted for both the massive red mudstone facies and the Montagne Noire basement (source) lithologies using two-dimensional (2-D) backscatter-electron (BSE) image analysis techniques modified from M. Soreghan and Francus (2004). We focused on quartz because of its resistance to chemical alteration and its application in interpreting wind-strength fluctuations within loesspaleosol successions (Porter and An, 1995; Xiao et al., 1995; M. Soreghan and Francus, 2004). Twelve digital BSE images per sample were acquired (at 760×; images $500 \mu \mathrm{m}$ across) using a Cameca SX100 electron probe micro-analyzer. For several granitic basement samples, images were acquired at lower magnification (at 125x; images $2000 \mu \mathrm{m}$ across) to accommodate larger quartz grains, and even then, quartz grains were commonly larger than the field of view (see for

${ }^{1}$ Supplemental Material. Sample location table (locations of measured sections and GPS coordinates of all samples collected for grain size, geochronological, and geochemical analysis) as well as supplementary images that were acquired for grain size analysis ("Appendix I"). Please visit https://doi.org/10.1130/GSAB.S.12268736 to access the supplemental material, and contact editing@ geosociety.org with any questions. 
Lodève basin (Salagou Formation)

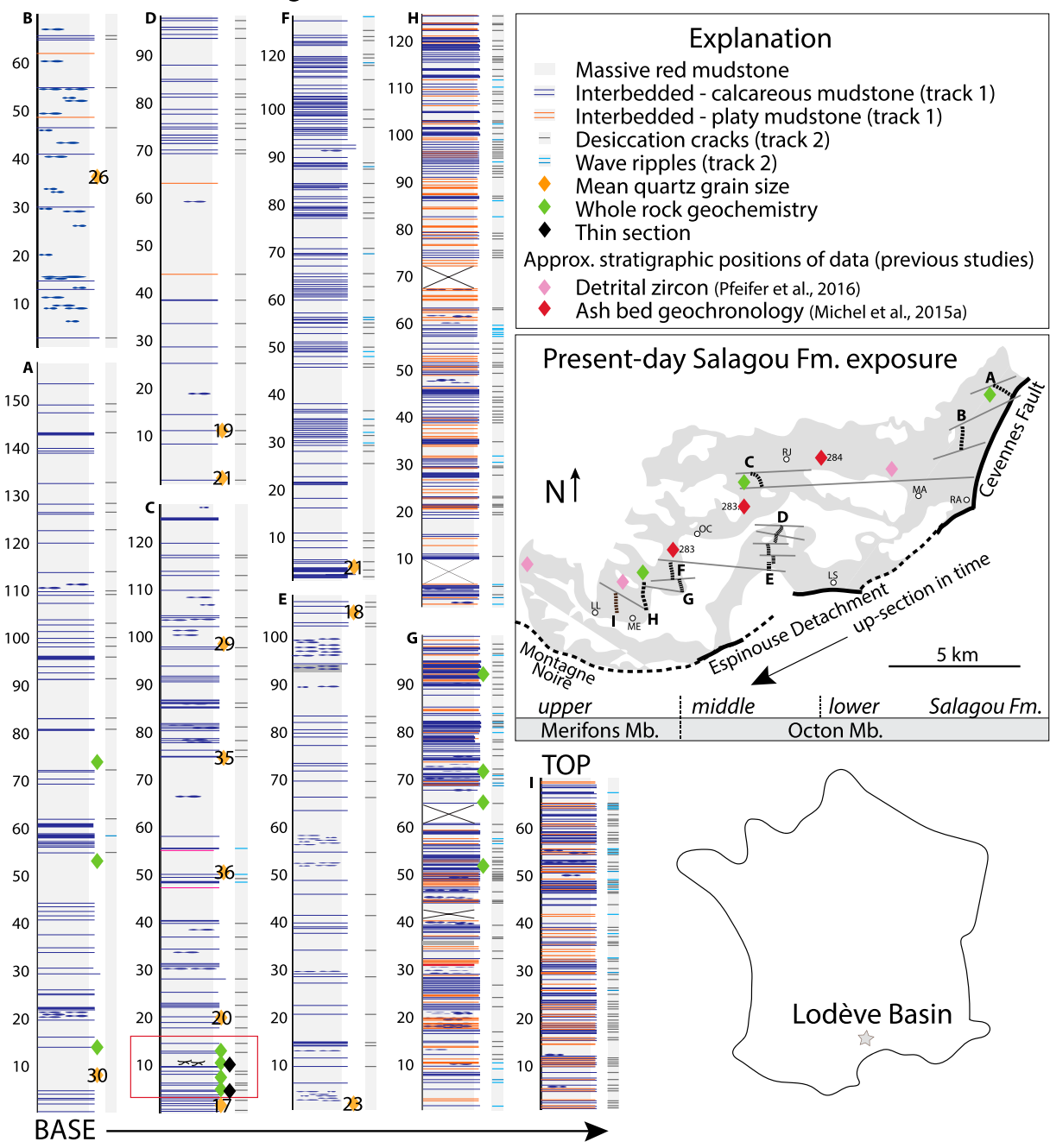

Figure 2. Stratigraphic logs of the Salagou Formation (Lodève Basin), 1000 m total. Base of section is on the bottom left, and top of section is at the top right. The wide column depicts the lithologies, and the second track (thinner column) denotes sedimentary structures (both at decimeter-scale resolution). Locations of data are shown with symbols in the key; mean quartz grain size $(n>100)$ for each sample is reported in microns with a number overlying the orange symbols. Red box indicates the position of the detailed pedogenic profile featured in Figures 4-6 and Table 2 ("paleosol" geochemistry). Inset map: Outcrop pattern of the Salagou Formation. Modern Lac Salagou and other Quaternary basalt/Mesozoic cover are shown in white. Approximate locations of villages for reference are shown with white points: Rabieux (RA), Mas Audran (MA), Rabejac (RJ), Octon (OC), Liausson (LS), Merifons (ME), and la Lieude (LL). This shows map-scale concatenation of segments of section (dashed black lines). Moving from the east to the west is generally moving from the base to the top of the section. See bottom bar for how our "lower," "middle," and "upper" formation designations relate to the Octon and Merifons Members (e.g., Schneider et al., 2006) and generally where this transition occurs (just east of Octon [OC]). Sequential sections were correlated laterally using map-scale projections of strike (dark gray). This approach might result in some unrepresented gaps between sections (poor exposure; most severe in the middle Salagou Formation). Estimated missing section totals $<\sim 500 \mathrm{~m}$. Southward dip of bedding is consistent but ranges from $\sim 5^{\circ} \mathrm{S}$ to $20^{\circ} \mathrm{S}$ (steeper toward $\mathrm{S}$-bounding detachment fault).

example Appendix $1^{1}$ ). If quartz was not distinct from plagioclase or dolomite (based on texture or grayscale), identification of each quartz grain was done with energy dispersive spectroscopy (EDS).
The silica-rich matrix of the Salagou Formation precluded automated differentiation of quartz and matrix by BSE contrast (as in M. Soreghan and Francus, 2004), so images were first processed by manually tracing quartz grains before being scanned into Image $J$ (National Institute of Health freeware package) to measure the crosssectional areas. Particle size distribution results depend on the method used: Laser diffraction (e.g., with laser particle-size analysis [LPSA]) enables measurement of three-dimensional (3D) grain size, whereas image analysis techniques on 2-D sample slices are fine-skewed and cannot resolve the finest $(<2 \mu \mathrm{m})$ phases (Soreghan and Francus, 2004; Varga et al., 2018). Additionally, this analysis focused exclusively on the quartz grains, to assess relative variations through the section, rather than absolute grain size. Stereological corrections to predict 3-D volume from a 2-D measurement are difficult in "multidispersal" systems that include a range of grain sizes and shapes (Sahagian and Proussevitch, 1998; M. Soreghan and Francus, 2004). To understand quartz grain-size results cast in a "truer" distribution, we applied a stereological correction for 2-D to 3-D conversion (Johnson, 1994), which did not substantially affect grainsize statistics (mean and mode increased by an average of $0.5 \mu \mathrm{m}$ and $0.8 \mu \mathrm{m}$, respectively; see Table 1).

\section{Geochemistry}

Whole-rock geochemistry (Table 2) was acquired from the lower $(n=3)$, middle $(n=3)$, and upper $(n=4)$ Salagou Formation. Additional samples included detailed sampling $(n=4$, $30 \mathrm{~cm}$ apart) of a profile in the middle Salagou Formation that displayed inferred macroscopic pedogenic features and a set $(n=5)$ of predominant source-rock lithologies (schist, granite, and tuff from the Montagne Noire dome). The chemical index of alteration (CIA; Nesbitt and Young, 1982; Price and Velbel, 2003; Joo et al., 2018) represents major-element proportions $\left(\mathrm{Al}_{2} \mathrm{O}_{3} /\left[\mathrm{Al}_{2} \mathrm{O}_{3}+\mathrm{CaO}+\mathrm{Na}_{2} \mathrm{O}+\mathrm{K}_{2} \mathrm{O}\right]\right)$ and is a proxy for the intensity of chemical weathering. We consider that grain size can affect CIA values (e.g., Whitmore et al., 2004; Hatano et al., 2019), but results allow for comparison of inferred pedogenic horizons and parent loess (in the basin), and assessment of the degree of chemical weathering in the paleohighlands (at the source). Similarly, the index of sodium depletion fraction $\left(\tau_{\mathrm{Na}}\right)$ assesses surface soil chemical weathering intensity by measuring the depletion of $\mathrm{Na}$ relative to immobile $\mathrm{Zr}$ with the equation $\tau_{\mathrm{Na}}=(\mathrm{Na} / \mathrm{Zr})_{\text {soil }} /(\mathrm{Na} / \mathrm{Zr})_{\text {protolith }}-1$ (Rasmussen et al., 2011; Yang et al., 2016). The $\tau_{\mathrm{Na}}-$ mean annual temperature (MAT) empirical transfer function (MAT $=-24.2 \times \tau_{\mathrm{Na}}$ 0.9) proposed by Yang et al. (2016) represents the dependence of surface chemical weathering intensity $\left(\tau_{\mathrm{Na}}\right)$ on air temperature (MAT) and 
TABLE 1. RESULTS OF QUARTZ GRAIN-SIZE ANALYSIS $(\mu \mathrm{m})$, SALAGOU FORMATION, LODĖVE BASIN, FRANCE

\begin{tabular}{|c|c|c|c|c|c|c|c|}
\hline & \multirow{2}{*}{$\begin{array}{c}\text { Grains } \\
\text { (no.) }\end{array}$} & \multirow[t]{2}{*}{ Mode } & \multirow[t]{2}{*}{ Median } & \multirow[t]{2}{*}{ Mean } & \multicolumn{3}{|c|}{ 3-D corrected ${ }^{*}$} \\
\hline & & & & & Mode & Median & Mean \\
\hline $\begin{array}{l}\text { Salagou Formation } \\
\text { Mid-upper } \\
\text { Mid-upper } \\
\text { Middle } \\
\text { Lower-mid } \\
\text { Lower } \\
\text { ALL } \\
\text { Difference* }\end{array}$ & $\begin{array}{r}120 \\
595 \\
312 \\
565 \\
254 \\
1846\end{array}$ & $\begin{array}{l}16 \\
17 \\
10 \\
10 \\
13 \\
17\end{array}$ & $\begin{array}{l}17 \\
17 \\
17 \\
23 \\
22 \\
19\end{array}$ & $\begin{array}{l}21 \\
19 \\
21 \\
28 \\
28 \\
23\end{array}$ & $\begin{array}{c}18 \\
9 \\
10 \\
11 \\
21 \\
17 \\
0.5\end{array}$ & $\begin{array}{l}18 \\
18 \\
18 \\
24 \\
23 \\
19 \\
0.7\end{array}$ & $\begin{array}{l}21 \\
19 \\
22 \\
29 \\
29 \\
24 \\
0.8\end{array}$ \\
\hline $\begin{array}{l}\text { Montagne Noire } \\
\text { Granite } 1 \\
\text { Granite } 2 \\
\text { Schist } 1 \\
\text { Schist } 2 \\
\text { Tuff }\end{array}$ & $\begin{array}{l}106 \\
115 \\
219 \\
223 \\
120 \\
\end{array}$ & $\begin{array}{r}209 \\
152 \\
25 \\
51 \\
108 \\
\end{array}$ & $\begin{array}{r}185 \\
163 \\
32 \\
55 \\
122 \\
\end{array}$ & $\begin{array}{r}191 \\
175 \\
31 \\
56 \\
127 \\
\end{array}$ & & & \\
\hline $\begin{array}{l}\text { Note: Values in tab } \\
\text { image analysis for th } \\
\text { interpreted source te } \\
\text { Locations within the } \\
\text { Member). } \\
\text { *Johnson (1994). }\end{array}$ & $\begin{array}{l}\text { statistic } \\
\text { agou Fo } \\
\text { Dark g } \\
\text { u Form }\end{array}$ & $\begin{array}{l}\text { stributio } \\
\text { ion (upp } \\
\text { results } \\
\text { are dep }\end{array}$ & $\begin{array}{l}\text { quartz gr } \\
\text { and for the } \\
\text { pplication } \\
\text { on Figure }\end{array}$ & $\begin{array}{l}\text { ize anal } \\
\text { tagne } \\
\text { e stereo } \\
\text { wer-mid }\end{array}$ & $\begin{array}{l}\text { esults } \\
\text { dome } \\
\text { al corre } \\
\text { Octor }\end{array}$ & $\begin{array}{l}\text { ckscatter } \\
\text {; Varisca } \\
\text { from Johi } \\
\text { ber; uppe }\end{array}$ & $\begin{array}{l}\text { ctron } \\
\text { ement, } \\
\text { (1994). } \\
\text { lerifons }\end{array}$ \\
\hline
\end{tabular}

TABLE 2. WHOLE-ROCK GEOCHEMISTRY, SALAGOU FORMATION, LODĖVE BASIN, FRANCE

\begin{tabular}{lcccccccccc}
\hline \hline & $\begin{array}{c}\text { Lower } \\
\text { loess }^{*}\end{array}$ & $\begin{array}{c}\text { Middle } \\
\text { loess }^{*}\end{array}$ & $\begin{array}{c}\text { Upper } \\
\text { loess }\end{array}$ & $\begin{array}{c}\text { Avg } \\
\text { loess }\end{array}$ & $\begin{array}{c}\text { Middle } \\
\text { paleosol }\end{array}$ & $\begin{array}{c}\text { Schist } \\
\text { basement }\end{array}$ & $\begin{array}{c}\text { Granite } \\
\text { basement }\end{array}$ & $\begin{array}{c}\text { UCC } \\
\text { standard }\end{array}$ & $\begin{array}{c}\text { NAQL } \\
\text { standard } \$\end{array}$ & $\begin{array}{c}\text { mmNASC } \\
\text { standard }\end{array}$ \\
\hline $\mathrm{SiO}_{2}$ & 59.5 & 61.9 & 61.2 & 60.9 & 58.4 & 81.0 & 75.6 & 66.0 & 80.2 & 60.4 \\
$\mathrm{Al}_{2} \mathrm{O}_{3}$ & 20.2 & 19.6 & 19.1 & 19.6 & 21.7 & 8.6 & 14.1 & 15.2 & 10.8 & 16.6 \\
$\mathrm{Fe}_{2} \mathrm{O}_{3}$ & 7.8 & 6.3 & 7.0 & 7.0 & 7.9 & 5.2 & 0.9 & 4.5 & 2.4 & 8.1 \\
$\mathrm{CaO}$ & 0.3 & 1.3 & 1.4 & 1.0 & 0.3 & 0.3 & 0.1 & 4.2 & 1.1 & 2.3 \\
$\mathrm{MgO}$ & 3.48 & 2.31 & 3.25 & 3.01 & 2.69 & 1.43 & 0.28 & 2.20 & 0.90 & 6.35 \\
$\mathrm{Na}$ & 2.36 & 4.16 & 3.32 & 3.28 & 3.32 & 0.71 & 1.24 & 3.90 & 1.60 & 1.80 \\
$\mathrm{~K}_{2} \mathrm{O}$ & 5.43 & 3.57 & 3.66 & 4.22 & 4.79 & 1.89 & 7.16 & 3.40 & 2.50 & 3.17 \\
$\mathrm{TiO}_{2}$ & 0.76 & 0.72 & 0.83 & 0.77 & 0.74 & 0.72 & 0.42 & 0.50 & 0.70 & 0.91 \\
$\mathrm{Zr}$ & 164 & 165 & 162 & 164 & 173 & 678 & 242 & 190 & 302 & 165 \\
$\mathrm{La}$ & 31.6 & 21.6 & 5.3 & 19.5 & 23.3 & 21.7 & 15.1 & 30.0 & 27.9 & 32.0 \\
$\mathrm{Th}$ & 6.6 & 3.5 & 1.1 & 3.7 & 5.1 & 3.3 & 2.6 & 10.7 & 8.6 & 10.3 \\
$\mathrm{Sc}$ & 9.0 & 5.3 & 2.0 & 5.4 & 7.3 & 3.5 & 2.0 & 11.0 & 7.8 & 18.0 \\
$\mathrm{ClA}$ & 66 & 60 & 62 & 63 & 66 & 70 & 59 & 46 & 60 & 61 \\
\hline
\end{tabular}

Note: Summary of whole-rock geochemistry and calculated chemical index of alteration $(\mathrm{CIA})$ values for the Salagou Formation and also for rock types of the Montagne Noire dome (Variscan basement, interpreted source terrane). Samples from inferred "loess" and "paleosol" units are labeled accordingly. The oxides are in percent, and the trace elements are in ppm. UCC—upper continental crust; NAQL-North American

Quaternary loess; mmNASC_-metamorphosed North American shale composite (for comparison).

*Lower, middle, upper refer to position in the Salagou Formation (see map on Fig. 2; lower-middle is Octon Member, and upper is Merifons Member).

†Taylor and McLennan (1985).

$\S$ Taylor et al. (1983).

"Gromet et al. (1984).

thus offers a quantitative method with which to estimate paleotemperatures $\left( \pm 2.7^{\circ} \mathrm{C}\right)$ from deep-time records.

\section{SEDIMENTOLOGIC DATA}

\section{Attributes of Salagou Formation Source Lithologies: Montagne Noire Dome}

Pfeifer et al. (2016) used detrital zircon geochronology and sandstone petrography to assess provenance of the Salagou Formation (Fig. 3. Detrital zircon analysis of three Salagou Formation samples (lower, middle, upper) all yielded a principal age peak of $460 \mathrm{Ma}$. The middle and upper Salagou Formation exhibited age distributions that included equally dominant age peaks at 287 and $294 \mathrm{Ma}$, respectively, whereas the basal sample from the Salagou Formation had a subordinate age peak at $311 \mathrm{Ma}$. These samples are quartzofeldspathic (31\%-44\% feldspar; 9:1 the Lodève Basin. The Montagne Noire dome consists of a deformed and metamorphosed Neoproterozoic to Lower Paleozoic series (schist and gneiss) intruded by Ordovician granites, and later by ca. 320-295 Ma granitoids. New quartz grainsize and geochemical data (CIA) for several of the predominant source lithologies are shown in Tables 1 and 2, respectively. Average (Neoproterozoic) schist $(n=2)$ CIA is 70 , with mean quartz grain sizes of 31-56 $\mu \mathrm{m}$. Average CarboniferousPermian granite $(n=2)$ CIA is 59 , and quartz grain sizes in most cases were too large for imaging on the probe, but two of the finer granite samples had mean quartz grain sizes of 175 and $191 \mu \mathrm{m}$, respectively. A Cambrian tuff from the study area $(n=1)$ exhibited a mean quartz grain size of $127 \mu \mathrm{m}$. We attempted a volumetric estimation for the CIA mode of the source as a whole using the geochemistry and hypothesized ratio $(70 \%$ schist and $30 \%$ granite) of these units in the source terrane and derived a CIA of $\sim 66$. However, we lacked geochemical data for other lithologies that were also actively eroding sources, as recorded by predominant peaks in detrital zircon data (e.g., the Ordovician orthogneiss). Unaltered CIA values of gneiss are typically quite low ( $\sim 50$; Tijani et al., 2006), so we would expect a more comprehensive estimation of volumetric CIA for the source terrane as a whole to be $<66$.

\section{Attributes of the Salagou Formation}

\section{Massive Red Mudstone Facies}

Description. The massive red to reddishbrown (5YR 5/8-5/6) mudstone facies (Fig. 4) is the most prevalent lithofacies, making up $90 \%$ of the lower-to-middle and $70 \%$ of the upper Salagou Formation. It occurs in tabular, laterally continuous beds that range in thickness from a few centimeters up to $15-20 \mathrm{~m}$, and it exhibits abrupt, nonerosive contacts with interbedded units. This facies is internally structureless and fractures in a blocky manner. It is well cemented and lacks grading, laminations, and preferred plagioclase:potassium), with subordinate proportions of metamorphic lithics $(14 \%-17 \%)$. These data record a predominant source within the Montagne Noire metamorphic core complex, a Variscan paleohigh located $<30 \mathrm{~km}$ W-SW of

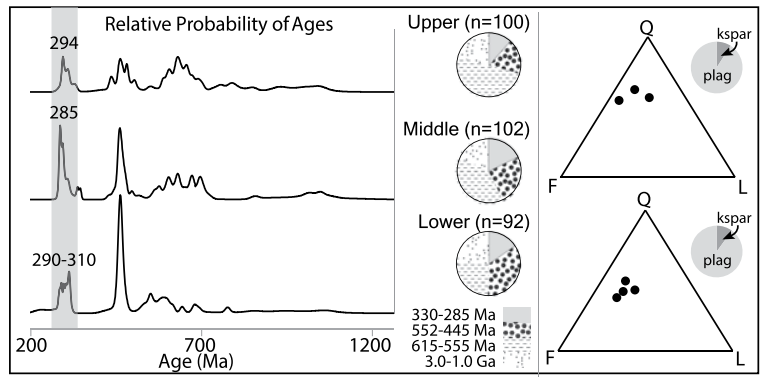

Figure 3. Summary of provenance data for the Salagou Formation (from Pfeifer et al., 2016). Left: Normalized probability plots of detrital zircon ages (and corresponding pie charts) from the lower, middle, and upper Salagou Formation, highlighting the youngest, late Paleozoic age peak. Right: Quartz-feldspar-lithics (QFL) ternary diagrams of framework modes from the lower and upper Salagou Formation (corresponding pie charts emphasize the high proportion of plagioclase [plag] relative to potassium feldspar [kspar], 9:1). 

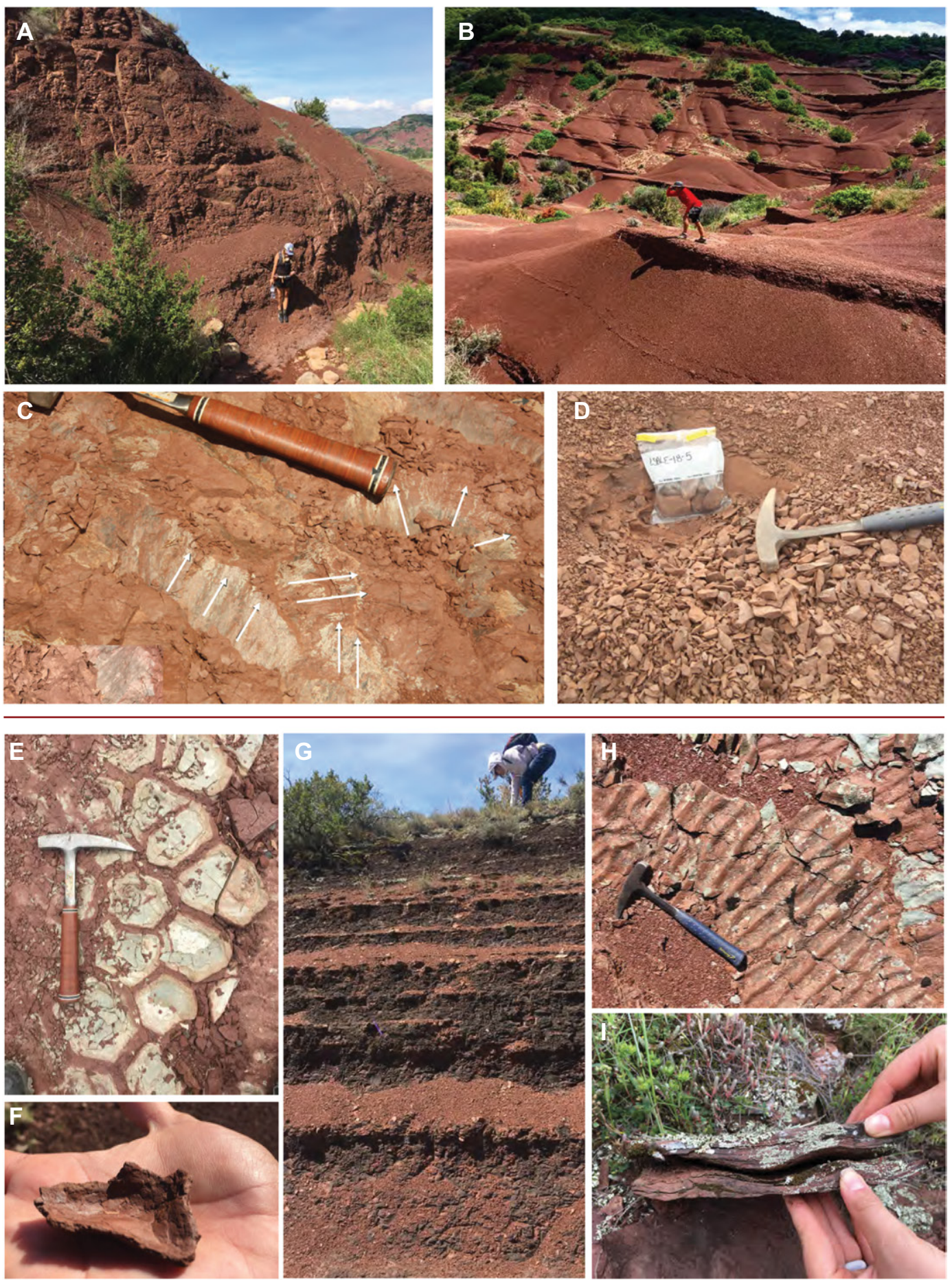

Figure 4. (A-I) Outcrop photos of representative facies. The massive red mudstone facies is characterized by massive, thick (15-20 $\mathrm{m})$ bedding $(\mathrm{A}-\mathrm{B})$, and areas with interpreted incipient pedogenesis include radial slickensides (C) and blocky fracturing $(D)$. The interbedded facies $(G)$ include: thin beds of calcareous mudstone $(E)$ with common desiccation cracks (F; note curled-up edges), and platy-fractured mudstone with millimeter-scale laminae, commonly with two-dimensional wave ripples (H-I). sedimentary fabric in thin section (Fig. 5). Modal analysis of nonmatrix grains $(n=7$; Fig. 3$)$ showed $\sim 50 \%$ quartz, $\sim 35 \%$ plagioclase feldspar (albite), and $\sim 15 \%$ lithics (metamorphic). Quartz grains are subangular, moderately sorted, and silt sized (mean overall $23 \mu \mathrm{m}$, mean range 19-28 $\mu \mathrm{m}$; Table 1). Most samples have a high proportion $(-50 \%)$ of fine-grained matrix consisting predominantly of illite with subordinate chlorite (and heavy minerals rutile, apatite, and hematite; Appendix 1 [see footnote 1]). These observations reinforce previous work (Michel, 2009), wherein X-ray diffraction (XRD) of the $<2 \mu \mathrm{m}$ fraction of the Octon Member (lower Salagou Formation) yielded clay compositions of illite and quartz with subordinate components of minerals from the chlorite-kandite group (undifferentiated). Other cements included silica, potassium feldspar, calcite, and dolomite. CIA values from the massive red mudstone in the upper, middle, and lower Salagou ranged from 60 to 66 (Table 2; average 63).

Interpretation. The fine (mud) grain size, thick and internally structureless beds, and local pedogenic overprinting (see below) of the massive red mudstone facies lead us to interpret these as loess deposits (e.g., Pye, 1987; Tsoar and Pye, 
A

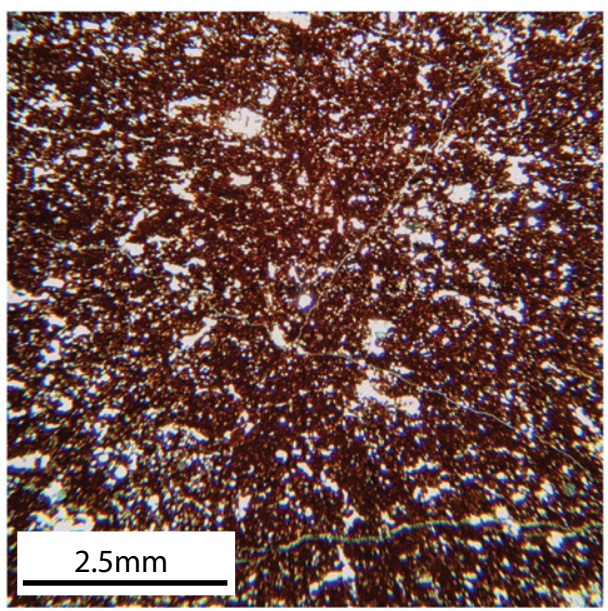

\section{B}

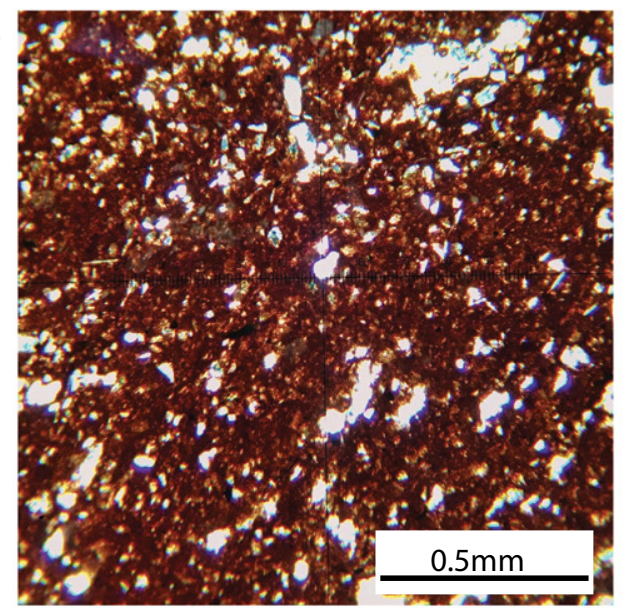

C

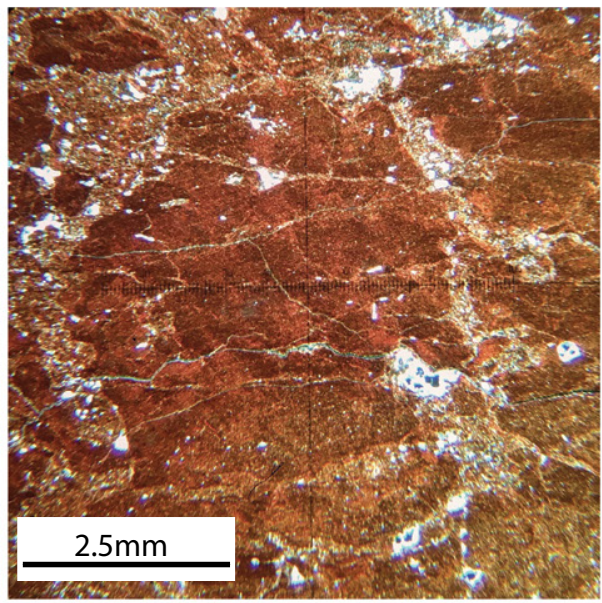

E

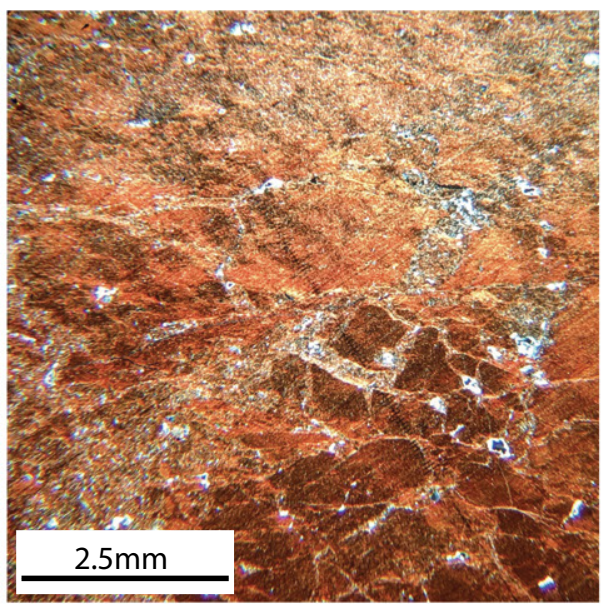

D

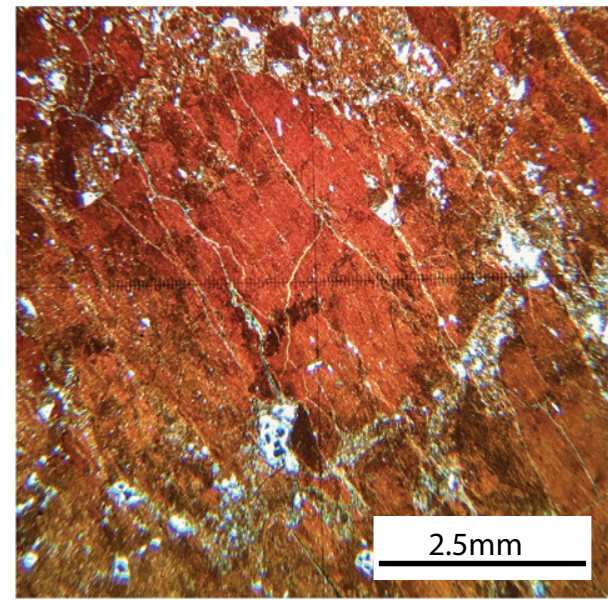

F

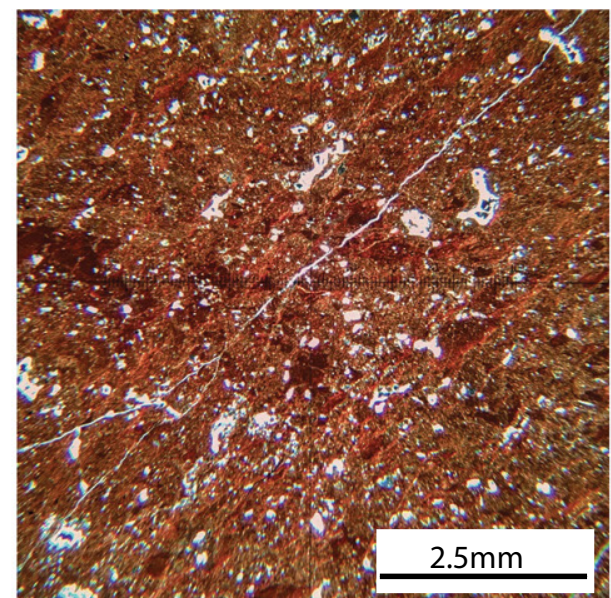

Figure 5. (A-F) Thin section photomicrographs of representative facies. The massive red mudstone is internally structureless (no preferred fabric) and composed of subangular, moderately sorted, silt-sized quartz in an illite-rich matrix (A-B). Micromorphologic attributes in pedogenic horizons include, for example, regions of birefringent clay (C-D), blocky peds $(\mathrm{E})$, and porphyroskelic fabric (F). Other features not shown here: circumgranular cracks, clay coatings on grains, and calcium carbonate nodules. Top of thin section is oriented to top of page in all photos except for $D$, wherein stage is rotated $\sim 5^{\circ}$ (top of slide oriented to the left edge of page).
1987; Johnson, 1989; Muhs, 2007; Soreghan and Soreghan, 2007, 2008a, 2008b; Sweet et al., 2013; Foster et al., 2014). Quartz grain-size means (19-28 $\mu \mathrm{m}$; Table 1) are uniform throughout the section. Note that mean grain sizes from the Salagou Formation are limited to the 2-D analysis of quartz grains and therefore cannot be compared in an absolute manner to "typical" loess size dis- tributions (e.g., 2-50 $\mu \mathrm{m}$; Muhs, 2018), which represent an analysis of the full particle distribution on disaggregated material. However, of all quartz grains analyzed $(n=1846), 97 \%$ were in the silt $(\sim 4-62 \mu \mathrm{m})$ range (78\% were in the range of medium silt, 6-30 $\mu \mathrm{m})$. Studies on Quaternary loess recognize considerable variability in both composition and grain size among loess bodies wherein predominant $\mathrm{SiO}_{2}$ ranges from $45 \%$ to $75 \%$ and grain size (typically $60 \%-90 \%$ within 2-50 $\mu \mathrm{m}$ ) fines with distance from source (Pye, 1987; Liu, 1988; Muhs and Bettis, 2003; Porter, 2001; Muhs et al., 2004; Muhs, 2018). This facies shares attributes with Upper Paleozoic loessite of the western United States, which are also mineralogically immature, angular to subangular, 
and feldspar rich (Johnson, 1989; Soreghan and Soreghan, 2007; Soreghan et al., 2008a), although it is possible that some albite in the Salagou Formation is authigenic (e.g., Schneider et al., 2006).

In ancient loessite, proportions of clay-sized material and/or true clay minerals also vary, increasing (up to $30 \%-50 \%$ ) with distance from source and within pedogenically modified horizons (e.g., Soreghan et al., 2002; Tramp et al., 2004; Soreghan and Soreghan, 2007). Similar to formerly termed "graywacke" sandstone (e.g., Dickinson, 1970, and others; see also Garzanti, 2017), "graywacke" mudstone in the Salagou Formation is difficult to evaluate given the apparently clay-rich matrix. Modern fine-fraction dust (very fine silt particles that are clay agglomerates) can reflect lacustrine deflation (e.g., diatomaceous material such as that of the Bodélé depression; e.g., Smalley et al., 2005), and "clay pellets" such as those recognized in the matrix of Triassic loessite (e.g., Wilkins et al., 2018). However, no evidence of clay pellets occurs in thin sections of mudstone from the Salagou Formation. Given the history of elevated temperature and burial in the Lodève Basin, combined with the well-documented volcanic centers in the greater region (see below; e.g. Soreghan et al., 2019; Michel et al., 2015a), the illite-dominant matrix likely reflects transformation from formerly smectitic clay-a common product of altered volcanic glass, feldspar, mafic silicates, and other aluminosilicates (Chamley, 1989; Tabor and Myers, 2015). Smectite forms in areas with moderate to low rainfall, and poor drainage, or in dry low latitudes (Chamley, 1989). Perhaps seasonal, shallow lacustrine conditions in the Lodève Basin sustained an environment sufficiently wet to convert fine ash to smectite. Subordinate chlorite was either sourced locally from chlorite-rich schists in the Montagne Noire dome, or it was also an alteration product of a distal (muscovite-rich) source.

The illite-rich pseudomatrix in the Salagou Formation likely represents long-range suspension of fine volcanic material that had a separate provenance from local coeval source terranes in the Montagne Noire dome ("coarser" Q-F-Lm fraction; Fig. 3). Recent work (Wilson et al., 2019) inferred distal volcanic sources as a substantial component in Lower Triassic loessite from the North Sea that exhibited similarly illiteenriched compositions. Additional work (clay mineralogy, geochemistry, and geochronology) is required to pinpoint the correlative volcanic source(s), but late Paleozoic ice age explosive (ignimbritic) volcanism peaked ca. 300-290 Ma (associated with Variscan orogenic collapse) near the paleo-equator (Soreghan et al., 2019, and references within). Discrete tuffs (284-
$282 \mathrm{Ma}$; Michel et al., 2015a) occur throughout the lower-middle Salagou Formation, so it is reasonable to infer that long-distance sourcing of volcanic aerosol dust defines the fine detrital matrix in the Salagou Formation.

The consistently low CIA values (average 63) of the massive red mudstone facies are similar to those of Upper Paleozoic loessite of western equatorial Pangea (average 59-60; Soreghan et al., 2002; Soreghan et al., 2008a), with values between those of unweathered granite and average shale (50-70; Nesbitt and Young, 1982). Furthermore, CIA values of the interpreted loessite approximate the modal CIA of the basement sources (59-70), reflecting a low degree of chemical weathering. CIA values from the Lodève Basin have been reported previously (Schneider et al., 2006; Lopez et al., 2008) and were similarly interpreted to reflect weak chemical weathering, attributed to maximum aridity in the upper Octon Member (roughly in the middle Salagou Formation).

\section{Pedogenic Intervals within the Massive Red Mudstone Facies}

Description. Large $(\sim 10+\mathrm{cm})$, randomly oriented, semiradial slickensides exist locally within the massive red mudstone facies (Fig. 4). The color (5YR 5/8-5/6) of these units and the mineralogy of clay matrix do not change from that in the massive mudstone facies, but the proportion of clay-rich matrix is on average slightly higher (Fig. 5). Discontinuous nodular bedding, and reduction halos around irregular, vertical traces that are abruptly truncated also occur within this facies. Micromorphologic attributes of samples from these localities include birefringent clay concentrations, wedge-shaped peds, circumgranular cracks, clay coatings on grains, calcium carbonate nodules, and porphyroskelic (Retallack, 2001) fabrics (e.g., Fig. 5). CIA values from these intervals average 66, and $\tau_{\mathrm{Na}}$ is -0.22 (Fig. 6).

Interpretation. Randomly oriented slickensides and rare root traces in the massive red mudstone facies are interpreted to reflect pedogenesis, an interpretation further confirmed by the micromorphological and geochemical characteristics. The lack of horizonation in these soil profiles reflects a combination of incipient soil development that persisted despite the continuous accumulation of eolian dust, and destruction of (any) primary horizonation by shrink-swell pedoturbation. The high clay content (illite matrix, likely smectite prior to diagenesis) and defining (macro and micro) attributes of interpreted pedogenic horizons are most closely analogous to modern Vertisols (Driese and Foreman, 1992; Ahmad, 1983; Gray and Nickelsen, 1989; Mack et al., 1993). Seasonal wetting and drying cause shearing and slickensides in the B horizon and desiccation cracks (described in following section) during dry seasons (Gray and Nickelsen, 1989; Mack et al., 1993), as well as microscale features such as wedge-shaped peds (Mack et al., 1993), clay coatings on peds or detrital grains (Nettleton and Sleeman, 1985; Driese and Foreman, 1992), and concentrated masses (globules) of hematite (Brewer, 1976), most of which are observable in thin section in these samples (Fig. 5). Horizons with interpreted pedogenically altered zones have elevated CIAs (average 66; Fig. 6) compared with those in the interpreted parent loessite (average 63), consistent with enhanced weathering during ephemerally wet intervals. Studies of Paleozoic loessite in the western United States revealed similar patterns, with elevated CIAs (up to 75) and aluminum in intercalated pedogenic horizons (Soreghan et al., 2002; Tramp et al., 2004; Soreghan et al., 2008a). Locally (lower-middle Salagou Formation), discontinuous nodular bedding and carbonate micronodules in thin section represent incipient soil development (e.g., weakly developed Calcisols) or the reworking of loess during wetter periods (Johnson, 1989; Mack et al., 1993; Michel, 2009). Water availability modulates the relative effectiveness of many pedogenic processes (Retallack, 2001; Sheldon and Tabor, 2009). Vertisol development typically indicates seasonal precipitation (Tabor and Myers, 2015); in the modern-Pliocene record, these form in regions (semiarid tropics) that receive $\sim 400 / 500-1000 \mathrm{~mm}$ of annual precipitation (e.g., Lepre, 2019). The presence of interpreted Vertisols in the Salagou Formation coupled with abundant evidence for intermittent shallow water (e.g., interbedded units described below) suggest seasonal precipitation $(\sim 400 \mathrm{~mm}+)$ consistent with in situ Na depletion. Thus, the $\tau_{\mathrm{Na}}$ of -0.22 corresponds with a MAT of $4.4{ }^{\circ} \mathrm{C}$ during pedogenesis (Fig. 6; Yang et al., 2016).

\section{Interbedded Facies}

Description. Thin (1-10 cm), resistant, planar and continuous beds of mudstone cap meter(s)thick packages of the massive mudstone facies and comprise up to $10 \%$ of the lower-middle and $30 \%$ of the upper Salagou Formation (Fig. 2). Bedding thicknesses of the intervening massive red mudstone facies decrease substantially in the upper part of the Salagou Formation, controlled by the increased occurrence of interbedded units. Calcareous mudstone interbeds (Figs. 4E-4F) commonly exhibit downwardly tapering polygonal desiccation cracks (commonly $\sim 10-20 \mathrm{~cm}$ in diameter and penetrating downward typically $1-3 \mathrm{~cm}$ but up to $8 \mathrm{~cm}$ ) with up-curled edges, as well as rare asymmetrical/symmetrical ripples (average wavelength of $3-4 \mathrm{~cm},<1 \mathrm{~cm}$ 
A

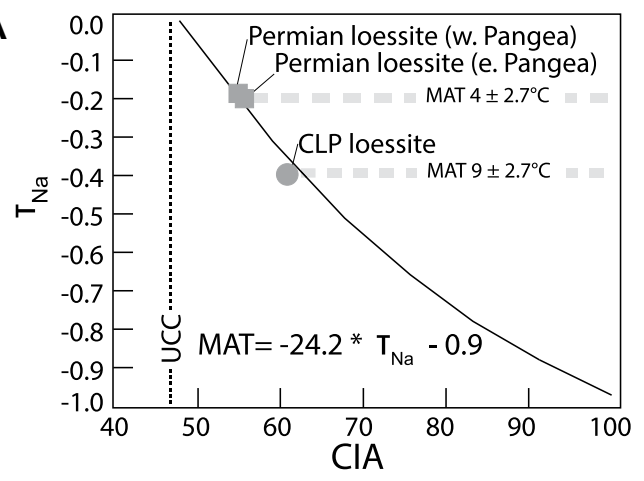

B
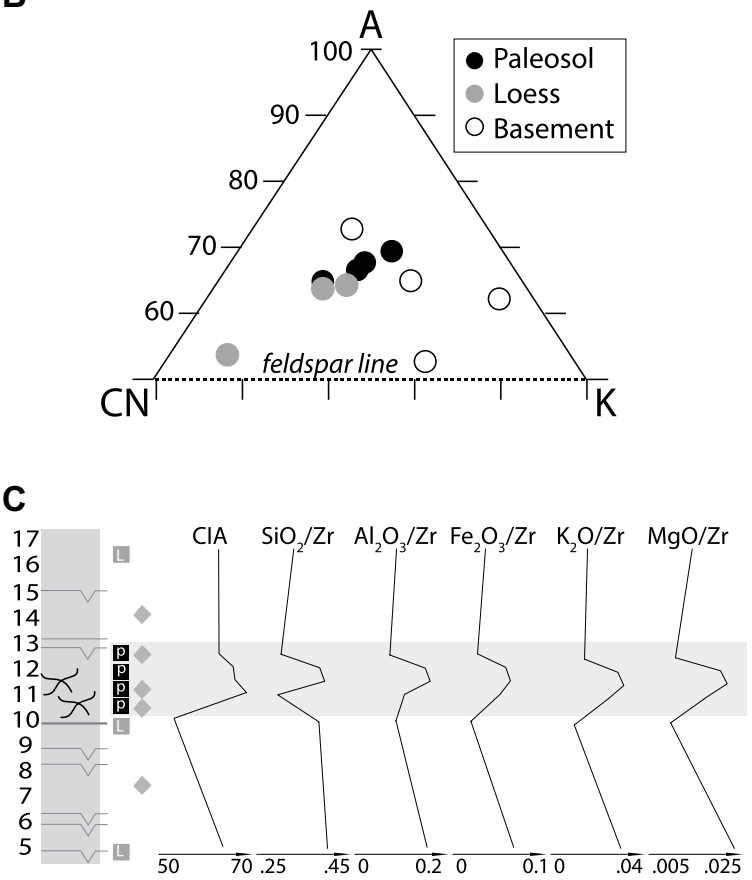

selected paleosol profile showing graphic $\log$ and trends in geochemical parameters normalized to zircon. Geochemical samples are denoted with squares, and thin section samples are denoted with diamonds. "Loess" (nonshaded area, "L"-labeled samples) is interpreted for areas that show minimal macro -or micro-evidence for pedogenesis (e.g., contains desiccation cracks, less clay, no peds), and "paleosol" (shaded area, "P"-labeled samples) is inferred based on the slickensided macromorphologies (Figs. 4C-4D) wherein micromorphologies (Figs. 5C-5F) contain pedogenic fabrics.

amplitude; Pochat et al., 2005) and fissile mud drapes. Platy laminated mudstone interbeds (Figs. 4H-4I) occur regularly only in the upper Salagou Formation. They are typically $3-5 \mathrm{~cm}$ (up to $10 \mathrm{~cm}$ ) thick, they are invariably reduced (buff to blue), and they exhibit platy fracturing along very thin (millimeter-scale) pervasive laminations. Hummocky cross-stratification (HCS) and asymmetrical/symmetrical wave ripples are common, and basal/upper contacts are abrupt.

Interpretation. Desiccation features also indicate that drying of saturated sediment or shallow water (clay shrinking) was common.
Figure 6. Summary of geochemical results from interpreted paleosol (lower-middle Salagou Formation), with position shown by the red box in Figure 2. (A) Correlation of weathering indices after Yang et al. (2016)—chemical index of alteration (CIA) and sodium depletion fraction $\left(\tau_{\mathrm{Na}}\right)$. Results from the Salagou Formation are indicated with the gray square. CIA $-\tau_{\mathrm{Na}}$ values from the Permian Maroon Formation, western equatorial Pangea (M. Soreghan et al., 2014b) are almost identical. CIA- $\tau_{\mathrm{Na}}$ values from the Chinese Loess Plateau (CLP; Yang et al., 2016) and upper continental crust (UCC; Taylor and McLennan, 1985) are shown for comparison. Mean annual temperature (MAT) values (calculated with the $\tau_{\mathrm{Na}}$-MAT transfer function proposed by Yang et al., 2016) are displayed adjacent to respective samples. (B) CIA ternary diagram (from feldspar line) showing the distribution between massive red mudstone, interpreted paleosols, and representative basement lithologies. Basement lithology high in $\mathrm{Al}$ is the schist. A-aluminum, $\mathrm{CN}$-calcium and sodium, and $\mathrm{K}$-potassium. CIA values are displayed on left side of diagram. (C) Detailed plots for .
Variable depths of crack penetration $(1-8 \mathrm{~cm})$ might relate to the intensity of seasonal precipitation (Tabor and Myers, 2015). Ripples and HCS record wind perturbation of a seasonally wet shallow lacustrine environment, but in the predominant red mudstone facies, there is no evidence of graded or laminated beds consistent with deep subaqueous deposition. The uniformly silt-sized grains and overall similar characteristics of these interbedded facies to the massive red mudstone facies suggest sediment was similarly delivered by eolian processes, wherein ephemeral standing water effectively

\title{
Noire
}

\author{
previ
} volume of fine-grained sedimn has not been previously identified.

\section{Silt Generation}

trapped settling dust. The sedimentary structures (laminations, ripples, desiccation features) and well-defined bedding that differentiate interbedded units from the predominant massive mudstone facies record subaqueous reworking and sorting of the sediment.

\section{DISCUSSION}

\section{Recognition of Permian Loess in Eastern Equatorial Pangea}

We postulate that the Salagou Formation facies exhibit characteristics most consistent with eolian transport and ultimate deposition as loess, with subordinate reworking of eolian-transported dust (clay and silt) into shallow lacustrine environments. Previous depositional interpretations of the Salagou Formation have focused primarily on the "interbedded" facies that contain positive evidence for the influence of water. However, the volumetric predominance of the massive mudstone (70\%-90\% of the unit) has proven relatively enigmatic owing to the absence of evidence for fluvial attributes such as channels, erosional scours, cross-stratification, or climbing ripple cross-stratified units. The uniform mud size also calls into question a fluvial interpretation. Although a general up-section increase occurs in interbedded units and sedimentary structures reflective of subaqueous deposition, the frequency and extent of interbedded units are vastly subordinate to the proportion of massive mudstone. Asymmetric ripples inferred to record Permian winds invariably are also associated with symmetrical ripples in the same bed (Pochat et al., 2005), and HCS and gutter casts represent combined flow during shallowlacustrine storm events. Provenance based on detrital zircon geochronology and petrography dicates sediment sourcing from the Montagne oire (located W-SW of the basin; Pfeifer et al.,

If the Salagou Formation is predominantly loess-whether deposited directly from the air as loess, or eolian-transported dust with final deposition in shallow, ephemeral lakes-then its great thickness $(\sim 1.5 \mathrm{~km}$ based on our measurements; Fig. 2) represents generation of an enormous amount of silt-sized quartz (in addition to fine-grained feldspar, metamorphic lithics, very fine-grained clay-rich matrix, and accessory phases). Several processes, including salt, chemical, or tectonic weathering, saltation-induced abrasion, weathering of silt-rich 
protoliths, fluvial comminution, deflation of siltrich (e.g., deltaic, floodplain) sources, and glacial grinding, are considered potentially capable of producing silt-sized grains, but their relative efficacy remains debated. Building on previous discussions by Soreghan et al. (2008a), Muhs (2013), and others, we reviewed the suitability of these processes and examined them in context of the Salagou Formation.

Nahon and Trompette (1982) considered tropical (chemical) weathering in modern systems as a primary mechanism to generate silt, but many subsequent studies suggested limited production of silt by these means (Pye and Mazzullo, 1994; Assallay et al., 1998; Wright, 2002, 2007). CIA values of the Salagou Formation loess (average 63), paleosols (average 66), and basement (maximum 66; see discussion above) are consistently low and overlap within error. Together with the preservation of labile phases $\left(\tau_{\mathrm{Na}}\right.$ of -0.22 and abundant plagioclase feldspar throughout the Salagou Formation), the geochemical data (Fig. 6) are inconsistent with a tropical weathering origin (Nesbitt and Young, 1996) and indicate sediment was sourced from a region dominated by physical weathering and/ or high altitude (e.g., Johnson, 1989; Soreghan et al., 2008a, 2014b).

Weathering of silt-rich protoliths such as siltstone, slate, phyllite, and volcanic rocks can release large quantities of "ready-made" silt (Kuenen, 1969; Blatt, 1987, 1989; Muhs and Bettis, 2003; Soreghan et al., 2016). In both mechanical and chemical weathering, granitic and gneissic sources tend to generate sand-sized quartz twice the size of quartz from schist (Blatt, 1967; Borrelli et al., 2014), although others suggest granite can release significant silt (e.g. Wright, 2007; discussion to follow). Detrital zircon data (Fig. 3) reveal a Carboniferous-Permian age population (310-285 Ma) that persists throughout deposition of the Salagou Formation and records derivation from coarse-grained (175$191 \mu \mathrm{m}$; Table 1) granitic protoliths of this age from the Montagne Noire dome. The absence of volcanic lithics in framework modes of the Salagou Formation (Fig. 3), together with the sizes of both quartz (19-28 $\mu \mathrm{m}$; Table 1) and zircon $(>>30 \mu \mathrm{m})$ grains, indicates the exclusively local provenance of Carboniferous-Permian detrital zircon as opposed to contributions from distal penecontemporaneous volcanic ash (inferred constituent of the illite-abundant matrix). Detrital zircon ages were obtained with a $30 \mu \mathrm{m}$ laser spot size, so dated grains were $>30 \mu \mathrm{m}$, and many were broken or rounded rather than the prismatic and euhedral shapes typical of volcanic grains. Other volcanic units in the immediate source area include Cambrian tuffs, which are minimally exposed and exhibit a coarse quartz grain size (127 $\mu \mathrm{m}$; Table 1$)$. Finally, the finest average quartz grain sizes from the Montagne Noire Neoproterozoic schists $(31-56 \mu \mathrm{m})$ exceed those $(19-28 \mu \mathrm{m})$ measured in all samples of the loessite (Table 1).

Experimental studies (Goudie et al., 1979; Wright and Smith, 1993; Wright, 2007) have demonstrated that some silt but mostly sand $(>70 \%)$ can be produced from parent rock in cases wherein (1) salt is available, and (2) the parent rock is susceptible to disaggregation (e.g., porous sandstone; Smith et al., 2002). The Salagou Formation contains little to no sandsized grains, and the source (Montagne Noire) is composed of granite, schist, and gneiss. Dust deflated from sabkha-playa systems would have an evaporitic (e.g., gypsiferous) or diatomaceous component (e.g., the Bodélé depression; Koren et al., 2006; Bristow and Moller, 2018). Previous workers have recognized pedogenic gypsum in the uppermost Salagou Formation (Merifons Member; Michel et al., 2015a), but it is neither abundant nor widespread. Hence, salt weathering is not a tenable solution for production of fines in this system.

The importance of silt generation in the form of "desert" loess-quartz fragmentation resulting from saltation-induced intergranular collisions-remains disputed (e.g., Smalley, 1990; Wright, 2001; Smith et al., 2002; Smalley et al., 2019). For example, some suggest that the large accumulations in the Chinese Loess Plateau originated in proximal deserts (Liu et al., 1994; Porter, 2001), whereas others suggest a glacial origin in the mountains of high Asia, followed by desert "storage" and ultimate deflation (e.g., Assallay et al., 1998; Smalley et al., 2005; Stevens et al., 2013; Li et al., 2018; Smalley et al., 2019). Formation of the silt in Permian-Pennsylvanian loessite in western Pangea was similarly linked initially to saltation abrasion in coeval sand dunes, owing primarily to the low-latitude setting (e.g., Johansen, 1988), but later work has called this into question. The quartzofeldspathic composition of these deposits is incompatible with coeval quartz-rich eolian sands, and silt from reworked dunes is commonly coarser (e.g., Johnson, 1989) or finer (Stuut et al., 2009) than typical "loess-size" grains (Whalley et al., 1987; Assallay et al., 1998; Bullard et al., 2004). Finally, the volumetrics of the loessite significantly exceed those of (potential) coeval eolian sandstone (Soreghan et al., 2008a, and references within). There is very little loess-sized silt documented in association with erg systems (e.g., Smalley and Vita-Finzi, 1968; Smalley and Krinsley, 1978; Tsoar and Pye, 1987; Smalley, 1990; Assallay et al., 1998; Muhs and Bettis, 2003; Smalley et al., 2005; Muhs, 2013; Smalley et al., 2019), consistent with experimental stud- ies that call into question the efficacy of making significant volumes of loess-sized quartz silt from saltation abrasion of eolian sand (Kuenen, 1959; Bullard et al., 2004; Swet et al., 2019; Adams and Soreghan, 2020). In the case of the Salagou Formation, grain-size modes, feldsparrich compositions, and sheer volume are similarly incompatible with a desert loess origin, especially considering the lack of coeval eolian sandstone in the greater region.

Mechanical comminution in high-energy fluvial systems has also been suggested as a means to produce silt, but experimental results show limited (and fine, 2-20 $\mu \mathrm{m}$ ) silt production (e.g., Kuenen, 1959; Moss et al., 1981; Wright and Smith, 1993; Smith and Swart, 2002). Silt-rich rivers occur primarily in regions either producing (high altitude, glacier proximal) or storing (e.g., Yellow River, Chinese Loess Plateau) large volumes of loess. Even in fluvial systems draining the Chinese Loess Plateau, particle sizes can include $>50 \%$ sand-sized grains (Jia et al., 2016). The importance of river systems in the distribution and concentration of loess prior to eolian deflation is recognized for most large Quaternary loess deposits (Smalley, 1995; Gallet et al., 1998; Wright, 2001), but silt produced by fluvial comminution alone is not consistent with the distribution of major loess deposits. Additionally, in the Lodève Basin study region, no evidence exists for coeval fluvial or deltaic systems, albeit highland-proximal systems are rarely preserved. These arguments suggest a minimal, if any, role for fluvial comminution in generating the fines in the Salagou Formation.

In summary, the effectiveness of salt weathering, tropical weathering, eolian and fluvial comminution, and derivation from precursor silt-rich units in producing abundant silt is limited, but moreover it is inconsistent with data from the Salagou Formation, especially in light of the comparably coarse grain size of known protoliths. Glacial grinding and associated periglacial processes (e.g., frost shattering) are effective mechanisms to comminute bedrock into large volumes of loess-sized silt (see Bryan, 1945; Kuenen, 1969; Smalley and Vita-Finzi, 1968; Boulton, 1978; Pye, 1987; Smalley, 1990, 1995; Wright et al., 1998; Assallay et al., 1998; Muhs and Bettis, 2003; Wright, 2001, 2007; Soreghan et al., 2008a, 2016; Muhs, 2013, 2018; Smalley et al., 2019). Smalley (1990, 1995) noted that most significant Quaternary loess relates to glacial processes (either directly or through an intermediate step) owing to the ease with which glacial systems produce the characteristic loess grain size (Boulton, 1978; Assallay et al., 1998). The great volume of loess-sized silt in the Salagou Formation, the coarse-grained protoliths, and mineralogical and geochemical data that 
reflect minimal chemical weathering are all most consistent with silt generation in a region dominated by physical, cold-weathering processes and/or at high altitude.

\section{Late Paleozoic Climatic Significance}

A possible glacial or periglacial origin for equatorial loess has significant bearing on the late Paleozoic climate system. Both true loessite and reworked loessite (e.g., marine carbonates with eolian-transported silt) have been documented across western equatorial Pangea (e.g., Soreghan et al., 2008a). Loess in the Salagou Formation-and correlatives in nearby basins (e.g., St. Affrique; Hübner et al., 2011)—whether blown in during glaciation or after being reworked, is interpreted to have been originally generated by glacial and periglacial mechanisms in the Variscan paleohighlands of eastern equatorial Pangea. Evidence for upland glaciation has been previously hypothesized for Upper Carboniferous deposits of the Lodève-Graissessac Basin (e.g. Julien, 1895; Grangeon, 1960; Dewolf, 1988; Sabrier et al., 1993; Becq-Giraudon and Van Den Driessche, 1994; Becq-Giraudon et al., 1996) but poorly accepted due to both the low paleolatitude $\left(0-15^{\circ} \mathrm{N}\right)$ of the Variscan Mountains, and the difficulty of inferring glaciation from highlands that are now eroded; no evidence of ice-contact facies has yet been documented, so only periglacial facies are potentially preserved.

Recent recognition of younger (LowerUpper Triassic, greenhouse) occurrences of loessite in both Europe and North America (e.g., Chan, 1999; Wilkins et al., 2018; Lawton et al., 2018; Wilson et al., 2019) raises the possibility of recycling of premade silt or erosion of volcanic origins. Gondwanan (continental) ice sheets persisted following "peak" ice (ca. $299 \mathrm{Ma}$ ) through the Sakmarian (ca. $290 \mathrm{Ma}$ ), decreased substantially through the Artinskian (ca. $283 \mathrm{Ma}$ ), and then persisted only in Australia through the Wuchiapingian (Soreghan et al., 2019). If equatorial upland (alpine) glaciation existed, we posit it might have persisted through the Sakmarian-Artinskian. Detrital zircon data from the Salagou Formation (Pfeifer et al., 2016) record the youngest (maximum depositional) age populations from the lower (287 $\pm 4 \mathrm{Ma})$, mid-upper $(285 \pm 3 \mathrm{Ma})$, and upper $(291 \pm 8 \mathrm{Ma})$ parts of the formation, and $\mathrm{U}-\mathrm{Pb}$ isotope dilutionthermal ionization mass spectrometry dates on inferred tuffs in the lower-mid-Salagou Octon Member (Michel et al., 2015a) range from 284 to $283 \mathrm{Ma}( \pm 0.1 \mathrm{Ma})$. Therefore, despite weak age control of the uppermost Salagou Formation (262 Ma absolute youngest; Evans, 2012), these ages indicate that most of the Salagou
Formation silt was generated during icehouse conditions. We cannot reject the possibility of a subordinate recycled or distal component, but these data substantiate the interpretation that loess generation and accumulation were essentially coeval with glacial conditions (within 10-15 m.y. of peak ice) and occurred relatively quickly, consistent with the extremely rapid 1-17 mm/yr exhumation of the source terrane (Pfeifer et al., 2016).

Glaciation has also been hypothesized for uplands of western equatorial Pangea (e.g., Uncompahgre uplift, Ancestral Rocky Mountains, $0-11^{\circ}$ ) in regions where inferred proglacial depositional systems can be traced toward epeiric shorelines, providing crude constraints on minimum elevations for ice-contact deposition persisting to within 1200-1600 m elevation (Soreghan et al., 2014a), an interpretation that calls for globally cooler paleotemperatures than those previously modeled for low latitudes in the late Paleozoic (Soreghan et al., 2014b). The $\tau_{\mathrm{Na}}$ values $(-0.19)$ from loessite in western equatorial Pangea (Maroon Formation, Colorado; Yang et al., 2016) together with $\tau_{\mathrm{Na}}$ values $(-0.22)$ from loessite in eastern equatorial Pangea (this study) correspond to MATs between 3.7 and $4.4 \pm 2.7^{\circ} \mathrm{C}$ at equatorial latitudes during deposition of Upper Pennsylvanian-Permian loess (Fig. 6). This estimated MAT is consistent with glaciation at moderate elevation (Variscan Mountains) in low-latitude Pangea.

Together with studies that document Pennsylvanian-Permian loessite in western equatorial Pangea (Murphy, 1987; Johnson, 1989; Kessler et al., 2001; Soreghan et al., 2002, 2008a, 2014b; Soreghan and Soreghan, 2007; Mack and Dinterman, 2002; Tramp et al., 2004; Sweet et al., 2013; Giles et al., 2013; Foster et al., 2014), this work documents widespread low-latitude accumulations of eolian dust in the Permian. We posit that the confluence of conditions necessary to generate and distribute such a remarkable volume of silt required widespread glaciation of upland regions near the equator (Central Pangean Mountains) and semiarid conditions in this lowlatitude region of accumulation, which-from a Quaternary perspective-is unusual. Major loess deposits of the Pliocene-Pleistocene that relate to glacial or periglacial processes occur in temperate, middle- to high-latitude regions (e.g., Muhs and Bettis, 2003; Li et al., 2019) and have been recognized as a "sedimentary extreme" (Chan and Archer, 2003) of unusually high silt production (Muhs and Bettis, 2003). Likewise, the volume and unique distribution (at equatorial latitudes) of the Pennsylvanian-Permian loess record represent a depositional and climatic extreme. We postulate that widespread loess/dust preservation during this interval—a signal that now spans across low-latitude Pangea-calls for a globally cooler Earth during the time(s) archived by the widespread, first-cycle loess. Evans (2003) classified ice distribution through Earth history into two categories-exclusively high latitudes during the Phanerozoic and exclusively low latitudes during the Precambrian. However, the icehouse mode for the late Paleozoic is perhaps better characterized by climate simulations (Feulner, 2017) that model a range of global MAT from $1.4{ }^{\circ} \mathrm{C}$ to $12{ }^{\circ} \mathrm{C}$ during the late Carboniferous (relative to $10-15{ }^{\circ} \mathrm{C}$ MAT during Pliocene-Pleistocene glaciations) and align with evidence for upland glaciation in equatorial Pangea (simulated MAT $\sim 0-10{ }^{\circ} \mathrm{C}$ throughout western and central equatorial Pangea under $\mathrm{CO}_{2}$ of $150 \mathrm{ppm}$ and a cold summer orbital configuration in Gondwanaland; Feulner, 2017).

\section{CONCLUSION}

The Salagou Formation is interpreted to record eolian transport and subsequent deposition as both true loess and as dust that was ultimately trapped in seasonally shallow lakes. The loess interpretation is based primarily on sedimentological characteristics (massive and homogeneous in macroscale observations to entirely fine-grained material with common pedogenic features in microscale observations) and a lack of evidence for fluvial deposition or suitable alternative interpretations for delivering such a large volume $(\sim 1.5 \mathrm{~km})$ of silt to the basin. The methods applied here (facies and petrographic analysis, geochemical assessment of parent loess and subordinate pedogenically altered horizons, and grain-size analysis of both the source lithologies and derived sediment) are applicable for recognizing well-lithified and diagenetically altered ancient loessite. This is the first documentation of Upper Paleozoic loessite in eastern equatorial Pangea and thus represents an important contribution in an increasingly recognized record of pre-Quaternary loess for the late Paleozoic ice age. The Salagou Formation, together with analogous Upper Paleozoic loess deposits that have been documented in western equatorial Pangea, records widespread accumulations of eolian-transported material into low-latitude basins. Provenance data, relatively feldsparrich compositions, and geochemical proxies (CIA and $\tau_{\mathrm{Na}}$-MAT values) suggest that the most parsimonious interpretation is that bulk silt generation reflects cold-weathering (glacial and periglacial) processes in the Variscan Mountains $\left(0-15^{\circ} \mathrm{N}\right)$. The global recognition of substantial loess deposits at low latitudes has significant implications for our understanding of the late Paleozoic equatorial climate system, which was semiarid and potentially cold enough at times to host ice (at elevation) at the equator. 


\section{ACKNOWLEDGMENTS}

This work was supported by the National Science Foundation (NSF) under International Research Experiences for Students (IRES) grant OISE-1658614 (principal investigators G.S. Soreghan, M.J. Soreghan) and also EAR-1338331 (Sedimentary Geology and Paleobiology Program; to G.S. Soreghan). Thanks go to M.J. Soreghan and L.E. Hunt for grain-size analysis and microprobe work, N.G. Heavens for suggestions, and to our 2018-2019 NSF IRES student participants (L. Alaniz, B. Birkett, S. Huntsman, J. Langston, J. Mueller, E. Simpson, V. Smith, K. Yeager). Thanks also go to our reviewers (J. Schneider and anonymous reviewer) and editors (B. Pratt and R. Strachan) for their assistance with improving this work. Financial support for partially offsetting publication costs was provided from the Office of the Vice President for Research and the Office of the Provost, University of Oklahoma.

\section{REFERENCES CITED}

Adams, S.M., and Soreghan, G.S., 2020, A test of the efficacy of sand saltation for silt production: Implications for the interpretation of loess: Geology, v. 48, https://doi .org/10.1130/G47282.1

Ahmad, N., 1983, Vertisols, in Wilding, L.P., Smeck, N.E., and Hall, G.F., eds., Pedogenesis and Soil Taxonomy II: The Soil Orders: New York, Elsevier, Developments in Soil Science 11B, p. 91-123, https://doi.org/10.1016/ S0166-2481(08)70614-7.

Assallay, A.M., Rogers, C.D.F., Smalley, I.J., and Jefferson, I.F., 1998, Silt: 2-62 $\mu \mathrm{m}$ : Earth-Science Reviews, v. 45 , p. $61-88$, https://doi.org/10.1016/ S0012-8252(98)00035-X.

Becq-Giraudon, J.F., and Van Den Driessche, J., 1994, Dépôts périglaciaires dans le Stephano-Autunien du Massif Central: Témoin de l'effondrement gravitaire d'un haut plateau Hercynien: Comptes Rendus de l'Academie des Sciences Paris, v. 318, p. 675-682.

Becq-Giraudon, J.F., Montenat, C., and Van Den Driessche, J., 1996, Hercynian high-altitude phenomena in the French Massif Central: Tectonic implications: Palaeogeography, Palaeoclimatology, Palaeoecology, v. 122, p. 227-241, https://doi.org/10.1016/00310182(95)00081-X

Blatt, H., 1967, Provenance determination and the recycling of sediments: Journal of Sedimentary Petrology, v. 37, p. 1031-1044.

Blatt, H., 1987, Oxygen isotopes and the origin of quartz: Journal of Sedimentary Petrology, v. 57, p. 373-377, https://doi.org/10.1306/212F8B34-2B24-11D7$8648000102 \mathrm{C} 1865 \mathrm{D}$.

Blatt, H., 1989, Flux of siliciclastic grains in sediments: Journal of Geological Education, v. 37, p. 243-249, https:// doi.org/10.5408/0022-1368-37.4.243.

Borrelli, L., Perri, F., Critelli, S., and Gulla, G., 2014, Characterization of granitoid and gneissic weathering profiles of the Mucone River basin (Calabria, Italy): Catena, v. 113, p. 325-340, https://doi.org/10.1016/ j.catena.2013.08.014 (corrigendum: https://doi .org/10.1016/j.catena.2014.03.011).

Boulton, G.S., 1978, Boulder shapes and grain-size distributions of debris as indicators of transport paths through a glacier and till genesis: Sedimentology, v. 25, p. 773-799, https://doi.org/10.1111/j.1365-3091.1978 .tb00329.x.

Brewer, R., 1976, Fabric and Mineral Analysis of Soils: New York, Krieger, 482 p.

Bristow, C.S., and Moller, T.H., 2018, Testing the auto-abrasion hypothesis for dust production using diatomite dune sediments from the Bodélé depression in Chad: Sedimentology, v. 65 , no. 4 , p. $1322-1330$, https://doi .org/10.1111/sed.12423.

Bryan, K., 1945, Glacial versus desert origin of loess: American Journal of Science, v. 243, p. 245-246, https://doi .org/10.2475/ajs.243.5.245

Bullard, J.E., McTainsh, G.H., and Pudmenzky, C., 2004, Aeolian abrasion and modes of fine particle production from natural red dune sands: An experimental study: Sedimentology, v. 51, p. 1103-1125, https://doi org/10.1111/j.1365-3091.2004.00662.x.

Burg, J.P., Van Den Driessche, J., and Brun, J.P., 1994, Synto post-thickening extension in the Variscan belt of Western Europe; modes and structural consequences: Comptes Rendus de l'Academie des Sciences Paris, v. 319 , p. $1019-1032$.

Chamley, H., 1989, Clay Sedimentology: New York, Springer-Verlag, 623 p., https://doi.org/10.1007/978-3-64285916-8.

Chan, M.A., 1999, Triassic loessite of north-central Utah: Stratigraphy, petrophysical character, and paleoclimate implications: Journal of Sedimentary Research, v. 69, p. 477-485, https://doi.org/10.2110/jsr.69.477.

Chan, M.A., and Archer, A.W., 2003, Introduction: A look at extreme depositional systems, in Chan, M.A., and Archer, A.W., eds., Extreme Depositional Environments: Mega End Members in Geologic Time: Geological Society of America Special Paper 370, p. 1-4, https://doi.org/10.1130/0-8137-2370-1.1.

Copard, Y., Disnar, J.R., Becq-Giraudon, J.F., and Boussafir, M., 2000, Evidence and effects of fluid circulation on organic matter in intramontane coalfields (Massif Central, France): International Journal of Coal Geology, v. 44, p. 49-68, https://doi.org/10.1016/S01665162(99)00049-X.

Crowley, T.J., Baum, S.K., and Hyde, W.T., 1991, Climate model comparison of Gondwanan and Laurentide glaciations: Journal of Geophysical Research, ser D, Atmospheres, v. 96, p. 9217-9226, https://doi .org/10.1029/91JD00530.

Dewolf, Y., 1988, Stratified slope deposits, in Clark, M.J., ed., Advances in Periglacial Geomorphology: New York, Wiley, p. 91-110.

Dickinson, W.R., 1970, Interpreting detrital modes of graywacke and arkose: Journal of Sedimentary Petrology, v. 40 , p. $695-707$.

Domeier, M., and Torsvik, T.H., 2014, Plate tectonics in the late Paleozoic: Geoscience Frontiers, 5, p. 303-350, http://doi.org/10.1016/j.gsf.2014.01.002.

Driese, S.G., and Foreman, J.L., 1992, Paleopedology and paleoclimatic implications of late Ordovician Vertic paleosols: Juniata Formation, southern Appalachians: Journal of Sedimentary Petrology, v. 62, no. 1, p. 71-83.

Evans, D.A., 2003, A fundamental Precambrian-Phanerozoic shift in Earth's glacial style?: Tectonophysics, v. 375, p. 353-385, https://doi.org/10.1016/S00401951(03)00345-7.

Evans, M.E., 2012, Magnetostratigraphy of the Lodève Basin, France: Implications for the Permo-Carboniferous reversed superchron and the geocentric axial dipole: Studia Geophysica et Geodaetica, v. 56, p. 725-734, https://doi.org/10.1007/s11200-010-0082-y.

Feulner, G., 2017, Formation of most of our coal brough Earth close to global glaciation: Proceedings of the National Academy of Sciences of the United States of America, v. 26, p. 1-5, https://doi.org/10.1073/ pnas. 1712062114

Fluteau, F., Besse, J., Broutin, J., and Ramstein, G., 2001, The Late Permian climate. What can be inferred from climate modelling concerning Pangea scenarios and Hercynian range altitude?: Palaeogeography, Palaeoclimatology, Palaeoecology, v. 167, p. 39-71, https:// doi.org/10.1016/S0031-0182(00)00230-3.

Foster, T.M., Soreghan, G.S., Soreghan, M.J., Benison, K.C., and Elmore, R.D., 2014, Climatic and paleogeographic significance of eolian sediment in the Middle Permian Dog Creek Shale (midcontinent U.S.): Palaeogeography, Palaeoclimatology, Palaeoecology, v. 402, p. 12-29, https://doi.org/10.1016/j.palaeo.2014.02.031.

Gallet, S., Jahn, B., Lano, B.V.V., Dia, A., and Rossello, E., 1998, Loess geochemistry and its implications for particle origin and composition of the upper continental crust: Earth and Planetary Science Letters, v. 156, p. 157-172, https://doi.org/10.1016/S0012-821X(97)00218-5.

Gand, G., Garric, J., and Lapeyrie, J., 1997, Biocénoses à Triopsidés (Crustacea, Branchiopoda) du Permien du bassin de Lodève (France): Geobios, v. 30 no. 5, p. 673-700, https://doi.org/10.1016/S00166995(97)80157-X

Garzanti, E., 2017, The maturity myth in sedimentology and provenance analysis: Journal of Sedimentary Research, v. 87, p. 353-365, https://doi.org/10.2110/jsr.2017.17.
Giles, J.M., Soreghan, M.J., Benison, K.C., Soreghan, G.S. and Hasiotis, S.T., 2013, Lakes, loess, and paleosols in the Permian Wellington Formation of Oklahoma, USA : Implications for paleoclimate and paleogeography of the midcontinent: Journal of Sedimentary Research, v. 83 , p. 825-846, https://doi.org/10.2110/jsr.2013.59.

Goudie, A.S., Cooke, R.U., and Doornkamp, J.C., 1979 The formation of silt from quartz dune sand from saltweathering processes in deserts: Journal of Arid Environments, v. 2, p. 105-112, https://doi.org/10.1016/ S0140-1963(18)31786-5.

Grangeon, M., 1960, Observations sur la sedimentation Houillere: Bulletin de la Société Géologique de France, v. S7-II, p. 630-650, https://doi.org/10.2113/gssgfbull S7-II.5.630.

Gray, M.B., and Nickelsen, R.P., 1989, Pedogenic slickensides, indicators of strain and deformation processes in redbed sequences of the Appalachian foreland: Geology, v. 17, p. 72-75, https://doi.org/10.1130/00917613(1989)017<0072:PSIOSA>2.3.CO;2.

Gromet, L.P., Dymek, R.F., Haskin, L.A., and Korotev, R.L., 1984, North American shale composite: Its compilation, major and trace element characteristics: Geochimica et Cosmochimica Acta, v. 48, p. 2469-2482, https://doi.org/10.1016/0016-7037(84)90298-9.

Hatano, N., Yoshida, K., and Sasao, E., 2019, Effects of grain size on the chemical weathering index: A case study of Neogene fluvial sediments in southwest Japan: Sedimentary Geology, v. 386, p. 1-8, https://doi .org/10.1016/j.sedgeo.2019.03.017.

Hübner, N., Körner, F., and Schneider, J., 2011, Tectonics, climate and facies of the Saint Affrique Basin and correlation with the Lodève Basin (Permian, Southern France): German Journal of Geology, v. 162, no. 2, p. 157-170, https://doi.org/10.1127/18601804/2011/0162-0157.

Jia, X., Li, Y., and Wang, H., 2016, Bed sediment particle size characteristics and its sources implication in the desert reach of the Yellow River: Environmental Earth Sciences, v. 75 , no. 11 , p. 950 , https://doi.org/10.1007/ s12665-016-5760-9.

Johansen, S.J., 1988, Origins of Upper Paleozoic quartzose sandstones, American Southwest: Sedimentary Geology, v. 56, p. 153-166, https://doi.org/10.1016/00370738(88)90052-8.

Johnson, M.R., 1994, Thin section grain size analysis revisited: Sedimentology, v. 41, p. 985-999, https://doi .org/10.1111/j.1365-3091.1994.tb01436.x.

Johnson, S., 1989, The significance of loessite in the Maroon Formation (Middle Pennsylvanian to Lower Permian), Eagle Basin, northwest Colorado: Journal of Sedimentary Petrology, v. 59, p. 789-791.

Joo, Y.J., Madden, M.E.E., and Soreghan, G.S., 2018, Anomalously low chemical weathering in fluvial sediment of a tropical watershed (Puerto Rico): Geology, v. 46, no. 8, p. 691-694, https://doi.org/10.1130/G40315.1.

Julien, A., 1895, Ancient glaciers de la periode Houillere dans le plateau central de la France: Annuaire du Club Alpin Français, v. 21, p. 1-28.

Keller, G.R., and Hatcher, R.D.J., 1999, Some comparisons of the structure and evolution of the southern Appalachian-Ouachita orogen and portions of the TransEuropean suture zone region: Tectonophysics, v. 314 no. 1-3, p. 43-68, https://doi.org/10.1016/S00401951(99)00236-X

Kessler, J.L.P., Soreghan, G.S., and Wacker, H.J., 2001, Equatorial aridity in western Pangea: Lower Permian loessite and dolomitic paleosols in northeastern New Mexico: Journal of Sedimentary Research, v. 71, p. 818-833, https://doi.org/10.1306/2DC4096B-0E4711D7-8643000102C1865D

Koren, I., Kaufman, Y.J., Washington, R., Todd, M.C., Rudich, Y., Martins, J.V., and Rosenfeld, D., 2006, The Bodélé depression: A single spot in the Sahara that provides most of the mineral dust to the Amazon forest: Environmental Research Letters, v. 1, no. 1, p. 1-5, https://doi.org/10.1088/1748-9326/1/1/014005.

Körner, F., 2006, Klima- und Sedimentationsmuster des peri-tethyalen, kontinentalen Perms-Interdisziplinäre Studien an redbeds des Lodève Beckens [Ph.D. thesis]: Freiburg, Germany, Universität Freiburg, 261 p.

Körner, F., Schneider, J.W., Hoernes, S., Gand, G., and Kleeburg, R., 2003, Climate and continental sedimentation 
in the Permian of the Lodève Basin (southern France), in Decandia, F.A., Cassinis, G., and Spina, A., eds., Late Paleozoic to Early Mesozoic Events of Mediterranean Europe, and Additional Regional Reports: Bolletino della Società Geologica Italiana Volume Speciale 2, p. 185-191.

Kuenen, P.H., 1959, Experimental abrasion: Fluviatile action on sand: American Journal of Science, v. 257, p. 172 190, https://doi.org/10.2475/ajs.257.3.172.

Kuenen, P.H., 1969, Origin of quartz silt: Journal of Sedimentary Petrology, v. 39 , p. 1631-1633, https://doi.org/10.1306/74D71ED3-2B21-11D7$8648000102 \mathrm{C} 1865 \mathrm{D}$

Lawton, T.F., Ruiz-Urena, J.E., Solari, L.A., Terrazas, C.T., Juárez-Arriaga, E., and Ortega-Obregón, C., 2018, Provenance of Upper Triassic-Middle Jurassic strata of the Plomosas uplift, east-central Chihuahua, Mexico, and possible sedimentologic connections with Colorado Plateau depositional systems, in Ingersoll, R.V., Lawton, T.F., and Graham, S.A., eds., Tectonics, Sedimentary Basins, and Provenance: A Celebration of the Career of William R. Dickinson: Geological Society of America Special Paper 540, p. 481-508, https://do .org/10.1130/2018.2540(22).

Lepre, C.J., 2019, Constraints on Fe-oxide formation in monsoonal Vertisols of Pliocene Kenya using rock magnetism and spectroscopy: Geochemistry Geophysics Geosystems, v. 20, no. 11, p. 4998-5013, https://doi .org/10.1029/2019GC008276.

Li, J., Song, Z., Ruan, L., Yang, L., Van Zwieten, L., Hu, Z., and Wang, H., 2019, The contribution of Asian dust in the pedogenesis of Ultisols in southeastern China determined by soil grain size: Journal of Soils and Sediments, v. 19, p. 232-240, https://doi.org/10.1007/ s11368-018-2012-5.

Li, L., Chen, J., Chen, Y., Hedding, D.W., Li, T., Li, L., Liu, X., Zeng, F., Wu, W., Zhao, L., and Li, G., 2018, Uranium isotopic constraints on the provenance of dust on the Chinese Loess Plateau: Geology, v. 46, no. 9 , p. 747-750, https://doi.org/10.1130/G45130.1.

Liu, C., Masuda, A., Okada, A., Yabuki, S., and Zi-Li, F., 1994, Isotope geochemistry of Quaternary deposits from the arid lands in northern China: Earth and Planetary Science Letters, v. 127 , p. 25-38, https://doi .org/10.1016/0012-821X(94)90195-3.

Liu, T.S., 1988, Loess in China II: Berlin, Springer, 224 p.

Lopez, M., Grand, G., Garric, J., Körner, F., and Schneider, J., 2008, The playa environments of the Lodève Permian basin (Languedoc-France): Journal of Iberian Geology, v. 34, no. 1, p. 29-56.

Mack, G.H., and Dinterman, P.A., 2002, Depositional environments and paleogeography of the Lower Permian (Leonardian) Yeso and correlative formations in New Mexico: The Mountain Geologist, v. 39, p. 75-88.

Mack, G.H., James, W.C., and Monger, H.C., 1993, Classification of paleosols: Geological Society of America Bulletin, v. 105, p. 129-136, https://doi .org/10.1130/0016-7606(1993)105<0129:COP $>2.3$. $\mathrm{CO} ; 2$.

Malavieille, J., Guihot, P., Costa, S., Lardeaux, J.M., and Gardien, V., 1990, Collapse of the thickened Variscan crust in the French Massif Central: Mont Pilat extensional shear zone and Saint-Étienne Upper Carboniferous basin: Tectonophysics, v. 177, p. 139-149, https:// doi.org/10.1016/0040-1951(90)90278-G

Matte, P., 1986, Tectonics and plate tectonic models for the Variscan belt of Europe: Tectonophysics, v. 126, p. 329 374, https://doi.org/10.1016/0040-1951(86)90237-4.

Ménard, G., and Molnar, P., 1988, Collapse of a Hercynian Tibetan Plateau into a late Palaeozoic European Basin and Range province: Nature, v. 334, p. 235-237, https://doi.org/10.1038/334235a0.

Michel, L.A., 2009, Petrographic, Petrologic, and Isotopic Study of Paleosol Carbonates from the Permo-Pennsylvanian Lodève Basin, France [Ph.D. thesis]: Dallas, Texas, Southern Methodist University, $253 \mathrm{p}$.

Michel, L., Tabor, N., Montañez, I., Schmitz, M., and Davydov, V., 2015a, Chronostratigraphy and paleoclimatology of the Lodève Basin, France: Evidence for a pan-tropical aridification event across the Carboniferous-Permian boundary: Palaeogeography, Palaeoclimatology, Palaeoecology, v. 430, p. 118-131, https:// doi.org/10.1016/j.palaeo.2015.03.020.
Michel, L., Schmitz, M., Tabor, N., Montañez, I., and Davydov, V., 2015b, Reply to the comment on "Chronostratigraphy and paleoclimatology of the Lodève Basin, France: Evidence for a pan-tropical Aridification event across the Carboniferous-Permian boundary": Palaeogeography, Palaeoclimatology, Palaeoecology, v. 441, p. 1000-1004, https://doi.org/10.1016/j.palaeo.2015.03.020.

Moss, A.J., Green, P., and Hutka, J., 1981, Static breakage of granitic detritus by ice and water in comparison with breakage by flowing water: Sedimentology, v. 28 , p. 261-272, https://doi.org/10.1111/j.1365-3091.1981. tb01679.x.

Muhs, D.R., 2007, Loess deposits, origins and properties, in Elias, S.A., ed., Encyclopedia of Quaternary Science, Volume 3: Amsterdam, Elsevier, p. 1405-1418.

Muhs, D.R., 2013, Loess and its geomorphic, stratigraphic, and paleoclimatic significance in the Quaternary, in Lancaster, N., Sherman, D.J., and Baas, A., eds., Treatise on Geomorphology, Volume 11: Aeolian Geomorphology: San Diego, California, Academic Press, p. 149-183, https://doi.org/10.1016/B978-0-12374739-6.00302-X.

Muhs, D.R., 2018, The geochemistry of loess: Asian and North American deposits compared: Journal of Asian Earth Sciences, v. 155, p. 81-115, https://doi .org/10.1016/j.jseaes.2017.10.032.

Muhs, D.R., and Bettis, E.A., 2003, Quaternary loess-paleosol sequences as an example of climatic extremes, in Chan, M.A., and Archer, A.W., eds., Extreme Depositional Environments: Mega End Members in Geologic Time: Geological Society of America Special Publication 370, p. 53-74, https://doi.org/10.1130/0-8137-2370-1.53.

Muhs, D.R., McGeehin, J.P., Beann, J., and Fisher, E., 2004, Holocene loess deposition and soil formation as competing processes, Matanuska Valley, southern Alaska: Quaternary Research, v. 61, p. 265-276, https://doi org/10.1016/j.yqres.2004.02.003.

Murphy, K., 1987, Eolian Origin of Upper Paleozoic Red Siltstones at Mexican Hat and Dark Canyon, Southeastern Utah [M.S. thesis]: Lincoln, Nebraska, University of Nebraska, p. 127

Muttoni, G., Kent, D.V., 2019, Adria as promontory of Africa and its conceptual role in the Tethys Twist and Pangea B to Pangea A transformation in the Permian: Rivista Italiana di Paleontogia e Stratigrafia, v. 125, p. 249-269, https://doi.org/10.13130/2039-4942/11437.

Nahon, D., and Trompette, R., 1982, Origin of siltstones; glacial grinding versus weathering: Sedimentology, v. 29 , p. 25-35, https://doi.org/10.1111/j.1365-3091.1982. tb01706.x.

Nesbitt, H.W., and Young, G.M., 1982, Early Proterozoic climates and plate motions inferred from major element chemistry of lutites: Nature, v. 299, p. 715-717, https:// doi.org/10.1038/299715a0.

Nesbitt, H.W., and Young, G.M., 1996, Petrogenesis of sediments in the absence of chemical weathering: Effects of abrasion and sorting on bulk composition and mineralogy: Sedimentology, v. 43, p. 341-358, https://doi .org/10.1046/j.1365-3091.1996.d01-12.x.

Nettleton, W.D., and Sleeman, J.R., 1985, Morphology of Vertisols, in Douglas, L.A., and Thompson, M.L., eds., Soil Micromorphology and Soil Classification: Soil Science Society of America Special Publication 15, p. 165-196.

Odin, B., 1986, Les Formations Permiennes, Autunien Supérieur à Thuringienne, du Bassin de Lodève (Hérault, France) [Ph.D. thesis]: Aix-en-Provence and Marseille, France, Université Aix-Marseille III, 392 p.

Parrish, J., 1993, Climate of the supercontinent Pangea: Chicago Journals, v. 101, no. 2, p. 215-233.

Pfeifer, L.S., Soreghan, G.S., Pochat, S., Van Den Driessche, J., and Thomson, S.N., 2016, Permian exhumation of the Montagne Noire core complex recorded in the Graissessac-Lodève Basin, France: Basin Research, v. 30, p. 1-14, https://doi.org/10.1111/bre.12197.

Pochat, S., and Van Den Driessche, J., 2011, Filling sequence in late Paleozoic continental basins: A chimera of climate change? A new light shed given by the Graissessac-Lodève basin (SE France): Palaeogeography, Palaeoclimatology, Palaeoecology, v. 302, p. 170-186, https://doi.org/10.1016/j.palaeo.2011.01.006.

Pochat, S., and Van Den Driessche, J., 2015, Comment on "Chronostratigraphy and paleoclimatology of the
Lodève Basin, France: Evidence for a pan-tropical aridification event across the Carboniferous-Permian boundary," by Michel, L.A., Tabor, N.J., Montañez, I.P., Schmitz, M.D., Davydov, V.I.: Palaeogeography, Palaeoclimatology, Palaeoecology, v. 430, p. 118-131, https://doi.org/10.1016/j.palaeo.2015.03.020.

Pochat, S., Van Den Driessche, J., Mouton, V., and Guillocheau, F., 2005, Identification of Permian paleowind direction from wave-dominated lacustrine sediments (Lodève Basin, France): Sedimentology, v. 52, p. 809-825, https://doi.org/10.1111/j.1365 3091.2005.00697.x.

Porter, S.C., 2001, Chinese loess record of monsoon climate during the last glacial-interglacial cycle: Earth-Science Reviews, v. 54, p. 115-128, https://doi.org/10.1016/ S0012-8252(01)00043-5.

Porter, S.C., and An, Z., 1995, Correlation between climate events in the North Atlantic and China during the last glaciation: Nature, v. 375 , p. $305-308$, https://doi .org/10.1038/375305a0

Price, J.R., and Velbel, M.A., 2003, Chemical weathering indices applied to weathering profiles developed on heterogeneous felsic metamorphic parent rocks: Chemical Geology, v. 202, p. 397-416, https://doi.org/10.1016/ j.chemgeo.2002.11.001

Pye, K., 1987, Aeolian Dust and Dust Deposits: London, Academic Press, $334 \mathrm{p}$

Pye, K., and Mazzullo, J., 1994, Effects of tropical weathering on quartz grain shape: An example from northeastern Australia: Journal of Sedimentary Research, v. 64, p. 500-507.

Quast, A., Hoefs, J., and Paul, J., 2006, Pedogenic carbonates as a proxy for palaeo- $\mathrm{CO}_{2}$ in the Palaeozoic atmosphere: Palaeogeography, Palaeoclimatology, Palaeoecology, v. 242, p. 110-125, https://doi.org/10.1016/ j.palaeo.2006.05.017.

Rasmussen, C., Brantley, S., Richter, D.B., Blum, A., Dixon, J., and White, A.F., 2011, Strong climate and tectonic control on plagioclase weathering in granitic terrain Earth and Planetary Science Letters, v. 301, p. 521530, https://doi.org/10.1016/j.epsl.2010.11.037.

Retallack, G.J., 2001, Soils of the Past: An Introduction to Paleopedology: Oxford, UK, Blackwell Science, Ltd., 520 p., https://doi.org/10.1002/9780470698716

Roscher, M., and Schneider, J., 2006, Permo-Carboniferous climate: Early Pennsylvanian to Late Permian climate development of central Europe in a regional and global context, in Lucas, S.G., Cassinis, G., and Schneider, J.W., eds., Non-Marine Permian Biostratigraphy and Biochronology: Geological Society [London] Special Publication 265, p. 95-136, https://doi.org/10.1144/ GSL.SP.2006.265.01.05

Sabrier, R., Delfaud, J., Causse, F., Marocco, R., and Toutin-Morin, N., 1993, Utilisation des associations de minéraux argileux pour la reconstitution des paléotopographies: Mégatoposéquence actuelle d'Equateur, Orogène pyrénéen à l' Oligo-miocène, Chaîne varisque du Var au Permien: Bulletin de l'Institut de Géologie du Bassin d'Aquitaine, v. 53, p. 13-26.

Sahagian, D.L., and Proussevitch, A.A., 1998, 3D particle size distribution from 2D observations: Stereology for natural applications: Journal of Volcanology and Geothermal Research, v. 84, p. 173-196, https://doi .org/10.1016/S0377-0273(98)00043-2.

Schneider, J., Körner, F., Roscher, M., and Kroner, U. 2006, Permian climate development in the northern peri-Tethys area: The Lodève Basin, French Massif Central, compared in a European and global context: Palaeogeography, Palaeoclimatology, Palaeoecology, v. 240 , p. 161-183, https://doi.org/10.1016/ j.palaeo.2006.03.057.

Schneider, J.W., Lucas, S.G., Werneburg, R., and Rößler, R., 2010, Euramerican late Pennsylvanian/Early Permian arthropleurid/tetrapod associations-Implications for the habitat and paleobiology of the largest terrestrial arthropod, in Lucas, S.G., Schneider, J.W., and Spielmann, J.A., eds., Carboniferous-Permian Transition in Canõn del Cobre, Northern New Mexico: New Mexico Museum of Natural History and Science Bulletin, v. 49, p. 49-70.

Schneider, J.W., Lucas, S.G., Scholze, F., Voigt, S., Marchetti, L., Werneburg, R., Golubev, V.K., Barrick, J.E., Klein, H., Oplu, S., Nemyrovska, T., Ronchi, A., Day, M.O., Silantiev, V.V., Rößler, R., Saber, H., Linnemann, 
U., Zharinova, V., and Shen, S.-Z., 2019, Late Paleozoic-early Mesozoic continental biostratigraphyLinks to the Standard Global Chronostratigraphic Scale: Palaeoworld (in press), https://doi.org/10.1016/ j.palwor.2019.09.001.

Sheldon, N.D., and Tabor, N.J., 2009, Quantitative paleoenvironmental and paleoclimatic reconstruction using paleosols: Earth Science Reviews, v. 95, no. 1-52, https://doi.org/10.1016/j.earscirev.2009.03.004.

Smalley, I.J., 1990, Possible formation mechanisms for the modal coarse silt quartz particles in loess: Quaternary International, v. 7-8, p. 23-27, https://doi .org/10.1016/1040-6182(90)90035-3.

Smalley, I.J., 1995, Making the material; the formation of silt-sized primary mineral particles for loess deposits: Quaternary Science Reviews, v. 14, p. 645-651, https:// doi.org/10.1016/0277-3791(95)00046-1.

Smalley, I.J., and Krinsley, D.H., 1978, Loess deposits associated with deserts: Catena, v. 5, p. 53-66, https://doi .org/10.1016/S0341-8162(78)80006-X.

Smalley, I.J., and Vita-Finzi, C., 1968, The formation of fine particles in sandy deserts and the nature of 'desert' loess: Journal of Sedimentary Petrology, v. 38, p. 768-774.

Smalley, I.J., Kumar, R., Dhand, K.O.H., Jefferson, I.F., and Evans, R.D., 2005, The formation of silt material for terrestrial sediments: Particularly loess and dust: Sedimentary Geology, v. 179 , p. 321-328, https://doi .org/10.1016/j.sedgeo.2005.06.011.

Smalley, I.J., Marshall, J., Fitzsimmons, K., Whalley, W.B., and Ngambi, S., 2019, Desert loess: A selection of relevant topics: Geologos, v. 25, no. 1, p. 91-102, https:// doi.org/10.2478/logos-2019-0007.

Smith, B.J., Wright, J.S., and Whalley, W.B., 2002, Sources of non-glacial, loess-size quartz silt and the origins of "desert loess": Earth-Science Reviews, v. 59, p. 1-26, https://doi.org/10.1016/S0012-8252(02)00066-1.

Smith, R.M.H., and Swart, R., 2002, Changing fluvial environments and vertebrate taphonomy in response to climatic drying in a mid-Triassic rift valley fill: The Omingonde Formation (Karoo Supergroup) of central Namibia: Palaios, v. 17, p. 249-267, https://doi.org/10.1669/08831351(2002)017<0249:CFEAVT>2.0.CO;2.

Soreghan, G.S., Soreghan, M.J., and Hamilton, M.A., 2008a, Origin and significance of loess in late Paleozoic western Pangaea: A record of tropical cold: Palaeogeography, Palaeoclimatology, Palaeoecology, v. 268, p. 234-259, https://doi.org/10.1016/j.palaeo.2008.03.050.

Soreghan, G.S., Soreghan, M.J., Poulsen, C.J., Young, R.A., Sweet, D.E., and Davogustto, O.C., 2008b, Anomalous cold in Pangaean tropics: Geology, v. 36, p. 659-662, https://doi.org/10.1130/G24822A.1.

Soreghan, G.S., Soreghan, M.J., Sweet, D.E., and Moore, K.D., 2009, Hot fan or cold outwash? Hypothesized proglacial deposition in the Upper Paleozoic Cutler Formation, western tropical Pangea: Journal of Sedimentary Research, v. 79, p. 495-522, https://doi .org/10.2110/jsr.2009.055.

Soreghan, G.S., Sweet, D.E., and Heavens, N.G., 2014a, Upland glaciation in tropical Pangaea: Geologic evidence and implications for late Paleozoic climate modeling: The Journal of Geology, v. 122, p. 137-163, https://doi .org/10.1086/675255

Soreghan, G.S., Joo, Y.J., Madden, M.E.E., and Van Deventer, S.C., 2016, Silt production as a function of climate and lithology under simulated comminution: Quaternary International, v. 399, p. 218-227, https:// doi.org/10.1016/j.quaint.2015.05.010.

Soreghan, G.S., Soreghan, M.J., and Heavens, N.G., 2019, Explosive volcanism as a key driver of the late Paleozoic ice age: Geology, v. 47, no. 7, p. 600-604, https:// doi.org/10.1130/G46349.1.

Soreghan, M.J., and Francus, P., 2004, Processing backscattered electron digital images of thin section, in Francus, P., ed., Image Analysis, Sediments and Paleoenvironments: Berlin, Springer, p. 203-225.

Soreghan, M.J., and Soreghan, G.S., 2007, Whole-rock geochemistry of Upper Paleozoic loessite, western Pangea: Implications for paleo-atmospheric circulation: Earth and Planetary Science Letters, v. 255, p. 117-132, https://doi.org/10.1016/j.epsl.2006.12.010.

Soreghan, M.J., Soreghan, G.S., and Hamilton, M.A., 2002 , Paleowinds inferred from detrital zircon geochronology of Upper Paleozoic loessite, western equatorial Pangea: Geology, v. 30, p. 695-698, https://doi org/10.1130/0091-7613(2002)030<0695:PIFDZG >2 $0 . \mathrm{CO} ; 2$.

Soreghan, M.J., Heavens, N., Soreghan, G.S., Link, P.K., and Hamilton, M.A., 2014b, Abrupt and high-magnitude changes in atmospheric circulation recorded in the Permian Maroon Formation, tropical Pangea: Geological Society of America Bulletin, v. 126, p. 569-584, https://doi.org/10.1130/B30840.1.

Stevens, T., Carter, A., Watson, T.P., Vermeesch, P., Ando, S., Bird, A.F., Lu, H., Garzanti, E., Cottam, M.A., and Sevastjanova, I., 2013, Genetic linkage between the Yellow River, the Mu Us desert and the Chinese Loess Plateau: Quaternary Science Reviews, v. 78, p. 355-368, https:// doi.org/10.1016/j.quascirev.2012.11.032.

Stuut, J.B., Smalley, I.J., and O'Hara-Dhand, K., 2009, Aeolian dust in Europe: African sources and European deposits: Quaternary International, v. 198, p. 234-245, https://doi.org/10.1016/j.quaint.2008.10.007.

Sweet, A.C., Soreghan, L.S., Sweet, D.E., Soreghan, M.J., and Madden, A.S., 2013, Permian dust in Oklahoma: Source and origin for middle Permian (FlowerpotBlaine) redbeds in western tropical Pangaea: Sedimentary Geology, v. 284-285, p. 181-196, https://doi .org/10.1016/j.sedgeo.2012.12.006.

Sweet, D.E., and Soreghan, G.S., 2008, Polygonal cracking in coarse clastics records cold temperatures in the equatorial Fountain Formation (Pennsylvanian-Permian, Colorado): Palaeogeography, Palaeoclimatology, Palaeoecology, v. 268, no. 3-4, p. 193-204, https://doi .org/10.1016/j.palaeo.2008.03.046.

Swet, N., Elperin, T., Kok, J.F., Martin, R.L., Yizhaq, H., and Katra, I., 2019, Can active sands generate dust particles by wind-induced processes?: Earth and Planetary Science Letters, v. 506, p. 371-380, https://doi .org/10.1016/j.epsl.2018.11.013.

Tabor, N.J., and Myers, T.S., 2015, Paleosols as indicators of paleoenvironment and paleoclimate: Annual Review of Earth and Planetary Sciences, v. 43, p. 333-363, https:// doi.org/10.1146/annurev-earth-060614-105355.

Tabor, N.J., and Poulsen, C.J., 2008, Paleoclimate across the late Pennsylvanian-Early Permian tropical palaeolatitudes: A review of climate indicators, their distribution, and relation to palaeophysiographic climate factors: Palaeogeography, Palaeoclimatology, Palaeoecology, v. 268, p. 293-310, https://doi.org/10.1016/ j.palaeo.2008.03.052.

Taylor, S.R., and McLennan, S.M., 1985, The Continental Crust; Its Composition and Evolution: An Examination of the Geochemical Record Preserved in Sedimentary Rocks: Oxford, UK, Blackwell Science Publications, $312 \mathrm{p}$.

Taylor, S.R., McLennan, S.M., and McCulloch, M.T. 1983, Geochemistry of loess, continental crustal composition and crustal model ages: Geochimica et Cosmochimica Acta, v. 47, p. 1897-1905, https://doi .org/10.1016/0016-7037(83)90206-5

Tijani, M.N., Okunlola, O.A., and Abimbola, A.F., 2006, Lithogenic concentrations of trace metals in soils and saprolites over crystalline basement rocks: A case study from SW Nigeria: Journal of African Earth Sciences, v. 46, no. 5, p. 427-438, https://doi.org/10.1016/ j.jafrearsci.2006.08.003.

Tramp, K.L., Soreghan, G.S., and Elmore, R.D., 2004, Paleoclimatic inferences from paleopedology and magnetism of the Permian Maroon Formation loessite (Colorado, USA): Geological Society of America Bulletin, v. 116, p. 671-686, https://doi.org/10.1130/B25354.1.

Tsoar, H., and Pye, K., 1987, Dust transport and the question of desert loess formation: Sedimentology, v. 34 p. 139-153, https://doi.org/10.1111/j.1365-3091.1987. tb00566.x.

Van Den Driessche, J., and Brun, J.P., 1989, Un modèle cinématique de l'extension paleozoique superieur dans le sud du Massif Central: Comptes Rendus de l'Academie des Sciences Paris, v. 309, p. 1607-1613.

Varga, G., Kovacs, J., Szalai, Z., Cserhati, C., and Ujvari, G., 2018, Granulometric characterization of paleosols in loess series by automated static image analysis: Sedimentary Geology, v. 370, p. 1-14.

Whalley, W.B., Smith, B.J., McAlister, J.J., and Edwards, A.J., 1987, Aeolian abrasion of quartz particles and the production of silt-size fragments: Preliminary results in Frostick, L., and Reid, I., eds., Desert Sediments: Ancient and Modern: Geological Society of America Special Publication 35, p. 129-138, https:// doi.org/10.1144/GSL.SP.1987.035.01.09.

Whitmore, G.P., Crook, K.A.W., and Johnson, D.P., 2004, Grain size control of mineralogy and geochemistry in modern river sediment, New Guinea collision, Papua New Guinea: Sedimentary Geology, v. 171, p. 129 157, https://doi.org/10.1016/j.sedgeo.2004.03.011

Wilkins, A., Hurst, A., Wilson, M., and Archer, S., 2018, Palaeo-environment in an ancient low-latitude, arid lacustrine basin with loessite: The Smith Bank Formation (Early Triassic) in the central North Sea, UK continental shelf: Sedimentology, v. 65, p. 335-359, https://doi .org/10.1111/sed.12382.

Wilson, M.J., Hurst, A., Wilkins, A.D., Wilson, L., and Bowen, L., 2019, Mineralogical evidence for multiple dust sources in an early Triassic loessite: Sedimentology, v. 67, p. 239-260, https://doi.org/10.1111/sed.12641.

Wright, J., 2001, "Desert" loess versus "glacial" loess Quartz silt formation, source areas and sediment pathways in the formation of loess deposits: Geomorphology, v. 36, p. 231-256, https://doi.org/10.1016/ S0169-555X(00)00060-X

Wright, J., 2002, Granitoid weathering profiles as a source of loessic silt: Transactions of the Japanese Geomorphological Union, v. 23, no. 5, p. 769-793

Wright, J., 2007, An overview of the role of weathering in the production of quartz silt: Sedimentary Geology, v. 202, p. 337-351, https://doi.org/10.1016/ j.sedgeo.2007.03.024.

Wright, J., and Smith, B., 1993, Fluvial comminution and the production of loess-sized quartz silt: A simulation study: Geografiska Annaler, Ser. A, Physical Geography, v. 75 , no. $1-2$, p. $25-34$, https://doi.org/10.1080/0 4353676.1993.11880380.

Wright, J., Smith, B., and Whalley, B., 1998, Mechanisms of loess-sized quartz silt production and their relative effectiveness: Laboratory simulations: Geomorphology, v. 23 , p. 15-34, https://doi.org/10.1016/ S0169-555X(97)00084-6.

Xiao, J., Porter, S.C., An, Z., Kumai, H., and Yoshikawa, S., 1995, Grain size of quartz as an indicator of winter monsoon strength on the Loess Plateau of central China during the last $130,000 \mathrm{yr}$ : Quaternary Research, v. 43, p. 22-29, https://doi.org/10.1006/ qres.1995.1003.

Yang, J., Cawood, P.A., Du, Y., Li, W., and Yan, J., 2016, Reconstructing Early Permian tropical climates from chemical weathering indices: Geological Society of America Bulletin, v. 128, no. 5-6, p. 739-751, https:// doi.org/10.1130/B31371.1.

Ziegler, A.M., Scotese, C.R., McKerrow, W.S., Johnson, M.E., and Bambach, R.K., 1979, Paleozoic paleogeography: Annual Review of Earth and Planetary Sciences, v. 7, p. 473-502, https://doi.org/10.1146/annurev. ea.07.050179.002353.

Ziegler, P.A., 1996, Geodynamic processes govern development of rifted basins, in Roure, F., Ellouz, N., Shien, V.S., and Skvortsov, L., eds., Geodynamic Evolution of Sedimentary Basins: Moscow, p. 19-67.

SCIENCE Editor: Rob Strachan Associate Editor: Brian Prat

ManusCript Received 16 December 2019

Revised ManusCript ReCEIVEd 24 MarCh 2020

MANUSCRIPT ACCEPTED 21 APRIL 2020

Printed in the USA 